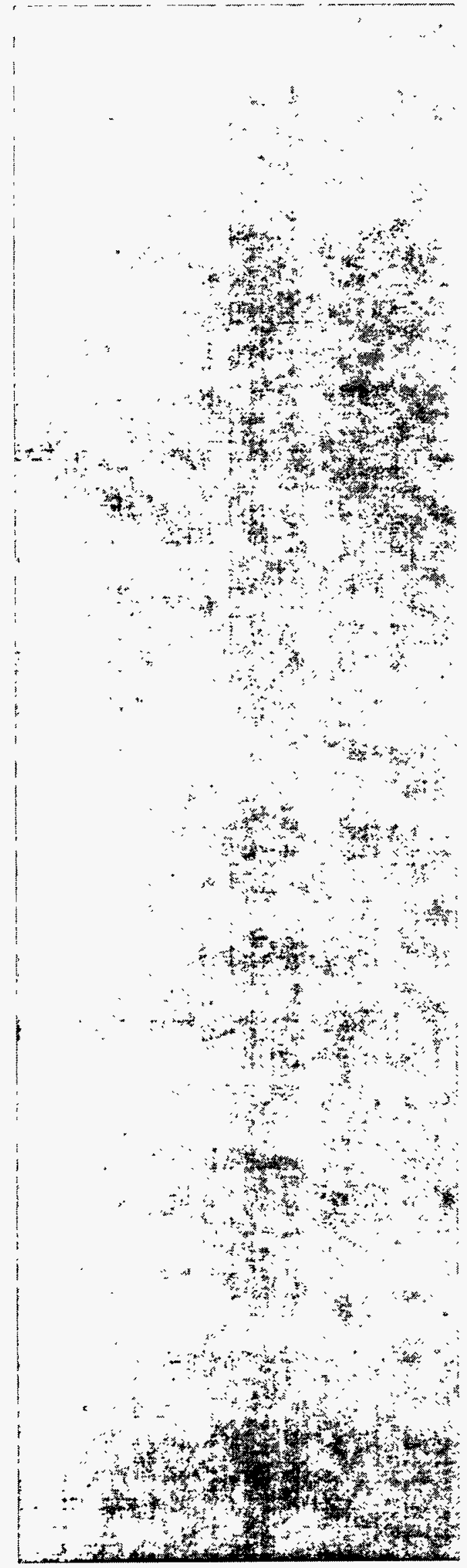

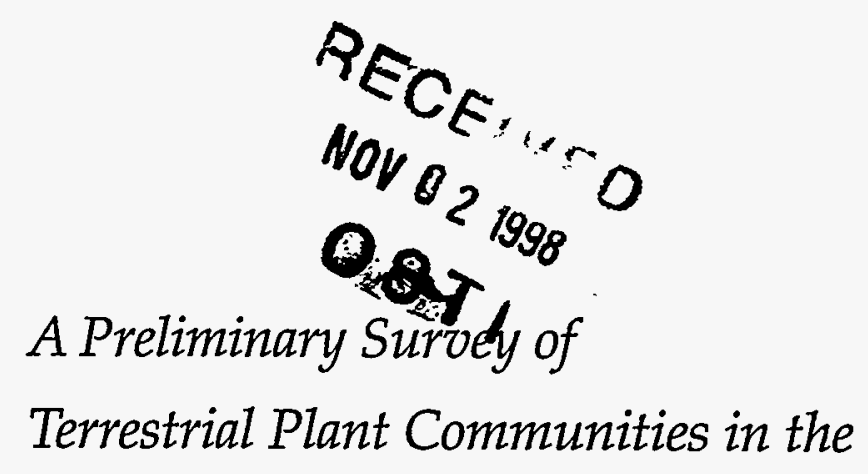

Sierra de los Valles

\section{Los Alamos \\ NATIONAL LABORATORY}

Los Alamos National Laboratory is operated by the University of California for the United States Department of Energy under contract W-7405-ENG-36. 


\section{Edited by Hector Hinojosa, Group CIC-1}

An Affirmative Action/Equal Opportunity Employer

This report was prepared as an account of work sponsored by an agency of the United States Government. Neither The Regents of the University of Califormia, the United States

Gooernment nor any agency thereof, nor any of their employees, makes any warranty, express or implied, or assumes any legal liability or responsibility for the accuracy, completeness, or usefulness of any information, apparatus, product, or process disclosed, or represents that its use would not infringe privately owned rights. Reference herein to any specific commercial product, process, or seroice by trade name, trademark, manufacturer, or otherwise, does not necessarily constitute or imply its endorsement, recommendation, or favoring by The Regents of the University of California, the United States Government, or any agency thereof. The views and opinions of authors expressed herein do not necessarily state or reflect those of The Regents of the University of California, the United States Government, or any agency thereof. Los Alamos National Laboratory strongly supports academic freedom and a researcher's right to publish; as an institution, however, the Laboratory does not endorse the viewpoint of a publication or guarantee its technical correctness. 


\section{DISCLAIMER}

Portions of this document may be illegible electronic image products. Images are produced from the best available original document. 
UC-902 and UC-908

Issued: October 1998

\section{A Preliminary Survey of}

Terrestrial Plant Communities in the

Sierra de los Valles

Randy G. Balice 


\section{CONTENTS}

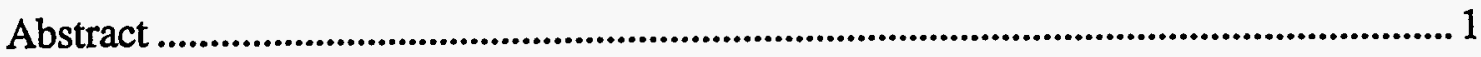

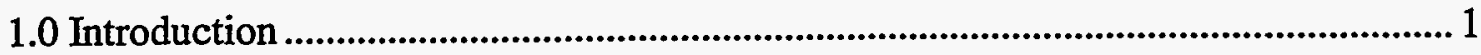

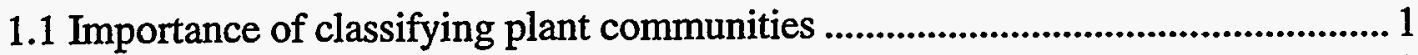

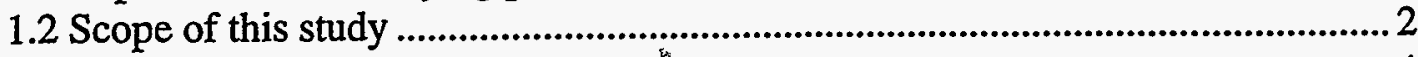

2.0 Environmental Setting............................................................................................... 4

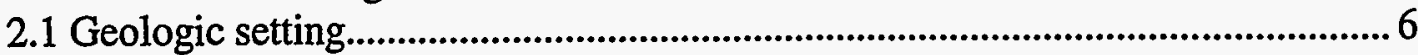

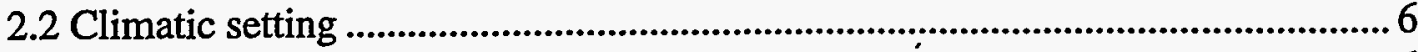

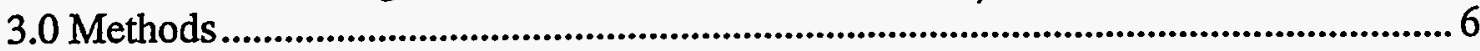

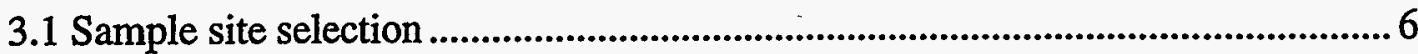

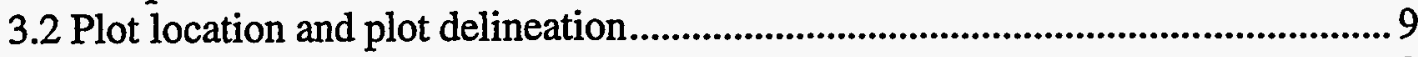

3.3 Randomization and subplot selection.....................................................................

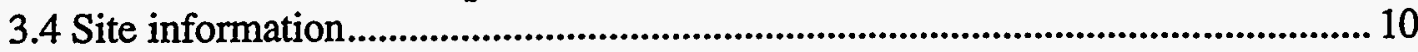

3.5 Overstory structures ............................................................................................... 10

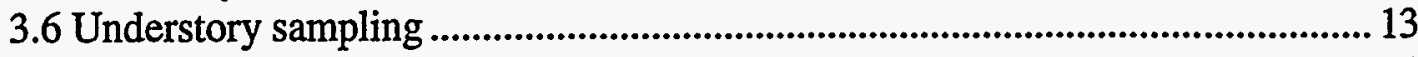

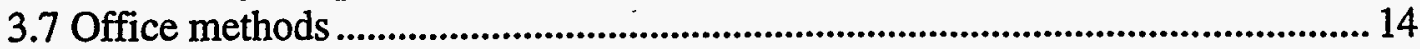

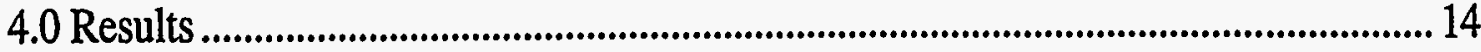

4.1 Ponderosa pine forests......................................................................................... 14

4.1.1 Ponderosa pine (Pinus ponderosa)/Gambel oak (Quercus gambelii) ............................................................................................. 15

4.1.2 Ponderosa pine (Pinus ponderosa)/Mountain muhly

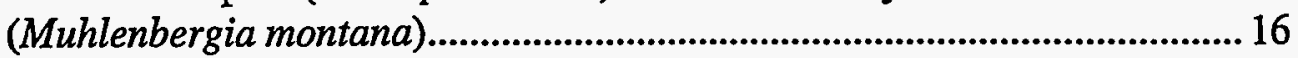

4.2 Mixed conifer forests .................................................................................................. 17

4.2.1 Douglas fir (Pseudotsuga menziesii)/Gambel oak (Quercus gambelii) .......................................................................................... 18

4.2.2 White fir (Abies concolor)/Gambel oak (Quercus gambelii)...................... 18

4.2.3 White fir (Abies concolor)/Kinnikinnik (Arctostaphylos uva-ursi) ................................................................................ 19

4.2.4 White fir (Abies concolor)/Mountain maple (Acer glabrum) ..................... 20

4.2.5 White fir (Abies concolor)/Forest fleabane (Erigeron eximius)..................21

4.3 Aspen forests ...................................................................................................... 21

4.3.1 Aspen (Populus tremuloides)/Bracken fern

(Pteridium aquilinum) ........................................................................................... 22

4.3.2 Aspen (Populus tremuloides)/Nodding brome

(Bromus anomalus) ............................................................................................... 22

4.4 Spruce-fir forsts...................................................................................................... 23

4.4.1 Engelmann spruce (Picea engelmannii)/Moss............................................. 24

4.4.2 Subalpine fir (Abies lasiocarpa)/Whortleberry

(Vaccinium myrtillus) ....................................................................................25

4.4.3 Subalpine fir (Abies lasiocarpa)/Forest fleabane

(Erigeron eximius)....................................................................................25

4.4.3 Subalpine fir (Abies lasiocarpa)/Aspen (Populus tremuloides) .................26

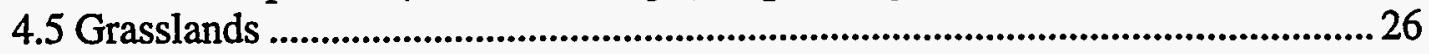

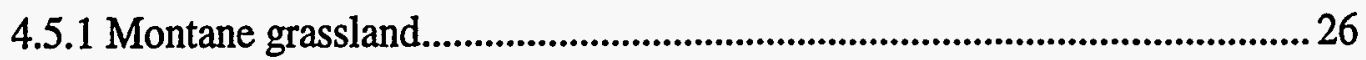




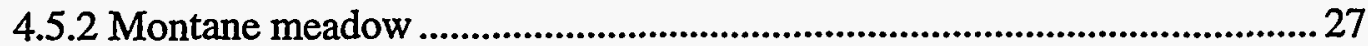

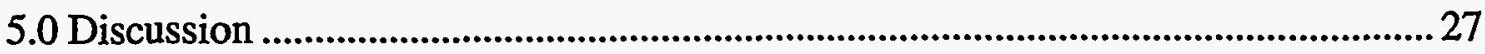

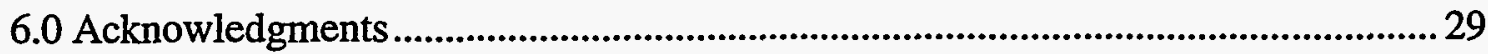

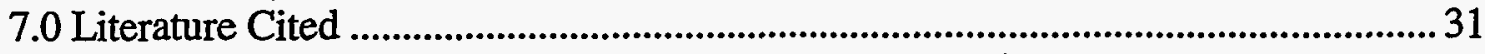

Appendix A: Correspondence Between the Common Names and

Scientific Names of Plant Species.................................................................................... 37

Appendix B: Correspondence Between the Scientific Names and

Common Names of Plant Species

Appendix C: Preliminary Key to Major Land Cover Types in the

Los Alamos Region, Revision 1 


\section{List of Figures}

Figure 1. Location of Los Alamos National Laboratory and its surroundings .......... 3

Figure 2. Los Alamos County and Los Alamos National Laboratory ........................ 5

Figure 3. Prominent land cover types in the fuels inventory region ........................ 7

Figure 4. Approximate locations of fuels inventory sample sites .......................... 11 


\title{
A Preliminary Survey of Terrestrial Plant Communities in the Sierra de los Valles
}

\author{
Randy G. Balice
}

\begin{abstract}
To more fully understand the species compositions and environmental relationships of high-elevation terrestrial plant communities in the Los Alamos region, 30 plots in randomly selected, upland locations were sampled for vegetation, topographic, and soils characteristics. The locations of these plots were constrained to be above $2,134 \mathrm{~m}(7,000 \mathrm{ft})$ above mean sea level. The field results were summarized, analyzed, and incorporated into a previously developed classification of vegetation and land cover types. The revised and updated discussions of the environmental relationships at these sites and their associated species compositions are included in this report. A key to the major land cover types in the Los Alamos region was also revised in accordance with the new information and included here in its entirety.
\end{abstract}

\subsection{Introduction}

\subsection{Importance of classifying plant communities}

A classification of plant communities serves many useful purposes that support the needs of land management and scientific research (Mueller-Dombois and Ellenberg 1974, Gauch 1982, Ferguson et al. 1987). Community classifications can provide insight into the productiveness and growth potentials of plant community types (Westfeld 1953, Daubenmire 1961, Ratliff and Pieper 1982). Knowledge of plant communities is also important for the understanding of the relative disease hazards from place to place (Thomas 1958, Shepherd 1959, Johnson et al. 1963).

With respect to management of wildlife, classifications of plant communities can be used to identify plant species that are indicators of bird habitat (Bunce et al. 1975). With this knowledge, the placement of roads and other developments may be planned accordingly. In a similar application, Thompson (1980) classified vegetation into types that have particular values for the assessment of wildlife use. Classifications of plant communities can also be used to determine the relationships between the sizes of bird populations and the successional status of the vegetation (Johnson and Odum 1956). There are numerous additional examples where classifications of plant communities have elucidated bird habitat and bird communities. These results have created opportunities for optimizing the design of management alternatives.

Land cover classifications have been useful for analyzing the potential sensitivities of environments and vegetation types to the location of a proposed gas pipeline (Orloci and Stanek 1979). In addition to environmental-vegetation relationships, ordination and classification of plant communities can elucidate important historical factors that pertain 
to management decision-making (Bratton 1975, Lindsay and Bratton 1979, Balice 1990). Moreover, classifications of plant communities can be combined with weather conditions, fuel loadings, and successional status to provide important tools in the management of fire, even during active suppression of forest fires (Kessell 1976, Kessell and Cattelino 1978).

In addition to having management importance, classifications of plant communities can also provide tools to solve many problems in scientific research. First, they are important to the design of experiments because they allow for replication of treatments in communities with similar potential (Lambert and Dale 1964, Daubenmire 1968, Balice 1990). Second they are an important first step in the interpretation of relationships between vegetation types and their soils and topographic and climatic environments (Whittaker 1975). Classifications of plant communities are also important for analyzing and understanding their successional relationships.

\subsection{Scope of this study}

In recent decades, selected plant communities of New Mexico and the Jemez Mountains area have been classified into natural groupings with much success (Castetter 1956, Layser and Schubert 1979, Moir and Ludwig 1979, Barnes 1983, Kennedy 1983, Moir and Hendzel 1983, Alexander et al. 1984, DeVelice et al. 1986, Alexander et al. 1987, Dick-Peddie 1993, USDA Forest Service 1995). Some of these efforts are general and comprehensive in nature, whereas others focus on specific classes of vegetation, such as coniferous forests or piñon-juniper woodlands. Plant communities in the Los Alamos area have also been described and classified (Foxx and Tierney 1980, Foxx and Potter 1981, Potter and Foxx 1981, Foxx and Tierney 1984, Foxx and Blea-Edeskuty 1995, Foxx 1996). The general region consisting of Los Alamos County, Los Alamos National Laboratory (LANL), and surrounding areas is shown in Figure 1.

To provide a tool for the Threatened and Endangered Species Habitat Management Program at LANL, these previous efforts were combined, summarized, and augmented with qualitative reconnaissance field data (Balice et al. 1977). The result was a preliminary, hierarchical vegetation and land cover classification. Ten Level-I vegetated and unvegetated cover types and 33 Level-II vegetated cover types were included. Nine unvegetated Level-II cover types were also incorporated into the hierarchical scheme. In addition, the discussion included synopses of the available information relative to management considerations and wildlife habitat. A dichotomous key to aid in the identification of the vegetation and land cover types was also developed.

During the process of developing this hierarchical land classification scheme, it was noted that further investigations are required to definitively describe the entire range of plant communities in the Los Alamos region and to define plant communities with limited distributions (Balice et al. 1977). In particular, our knowledge of the terrestrial plant communities at higher elevations in the Los Alamos region, above 2,134 $\mathrm{m}(7,000$ $\mathrm{ft}$ ) above mean sea level, would benefit from more intensive study. 


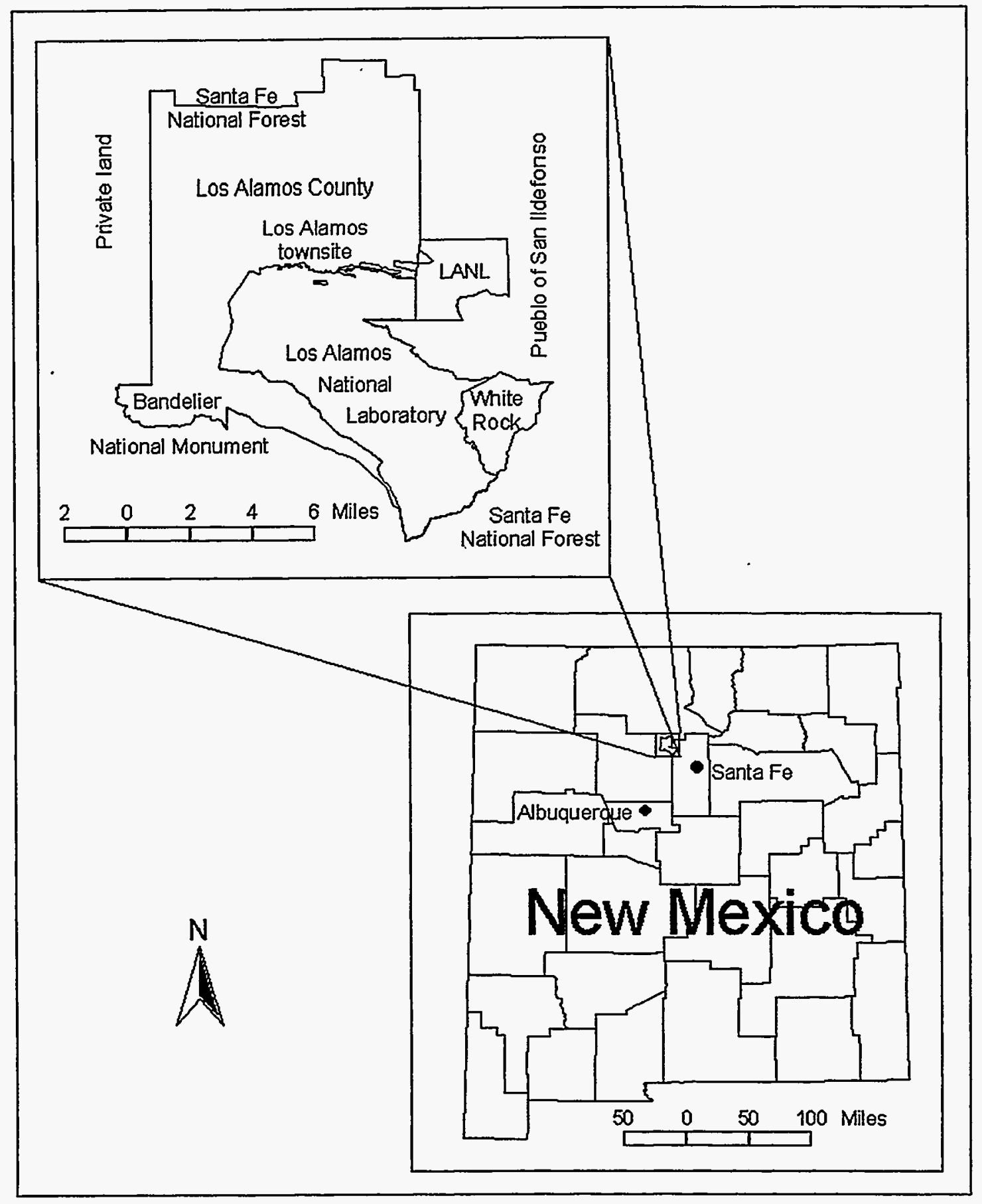

Figure 1. Location of Los Alamos National Laboratory and its surroundings. 
To gain this benefit, a quantitative, reconnaissance survey was conducted of selected

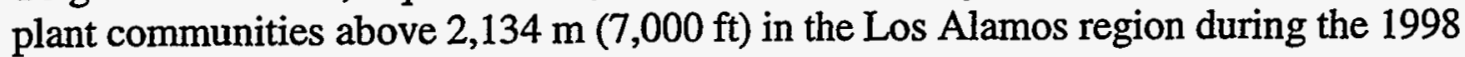
field season. At these sample locations, topographic and environmental parameters were also measured, and soils were evaluated. The resulting data were then analyzed by table rearrangement methods. These results were used to update and modify appropriate segments of the preliminary vegetation and land cover classification reported by Balice et al. (1997).

In accordance with these research objectives and general design, this report discusses terrestrial and upland plant communities that normally occur above $2,134 \mathrm{~m}(7,000 \mathrm{ft})$ above mean sea level. This primarily consists of the mixed conifer and spruce-fir zones. It also includes portions of the ponderosa pine zone and selected grassland communities. The previous descriptions of the environmental relationships and the species compositions of the selected plant communities in these zones are revised and updated, according to new information that was gained during the 1998 field season. However, for detailed discussions of the management and wildlife implications of these community types and for information relative to lower-elevation community types, the reader should refer to Balice et al. (1997).

The high-elevation segments of the "Preliminary Key to the Major Land Cover Types in the Los Alamos Region," previously published by Balice et al. (1997), has also been revised to reflect new information gathered during the 1998 field season. For the convenience of the user, the revised key is included in this report in its entirety.

\subsection{Environmental Setting}

The region of interest to this study is located on the eastern slopes of the Jemez Mountains, approximately $120 \mathrm{~km}(80 \mathrm{mi})$ north of Albuquerque and $40 \mathrm{~km}(25 \mathrm{mi})$ northwest of Santa Fe (Figure 1). The general Los Alamos region encompasses a wide range of environmental conditions. This is due in part to the prominent elevational gradient in the east-west direction (Figure 2).

The area of interest to this study is in the western portions of Los Alamos County, including portions of LANL and Bandelier National Monument (Figure 2). All of the fieldwork was conducted above 2,134 (7,000 ft) above mean sea level and most of it was conducted in a core area, on the eastern slopes of the Sierra de los Valles from Los Alamos townsite to the southern limits of Los Alamos County. Some of the work was also conducted in the western extremities of the Pajarito Plateau to the east of the core area, and in western portions of Pueblo and Bayo Canyons to the northeast of the core area. The core area of this project largely corresponded to the Valle Project area, established by the Santa Fe National Forest. 


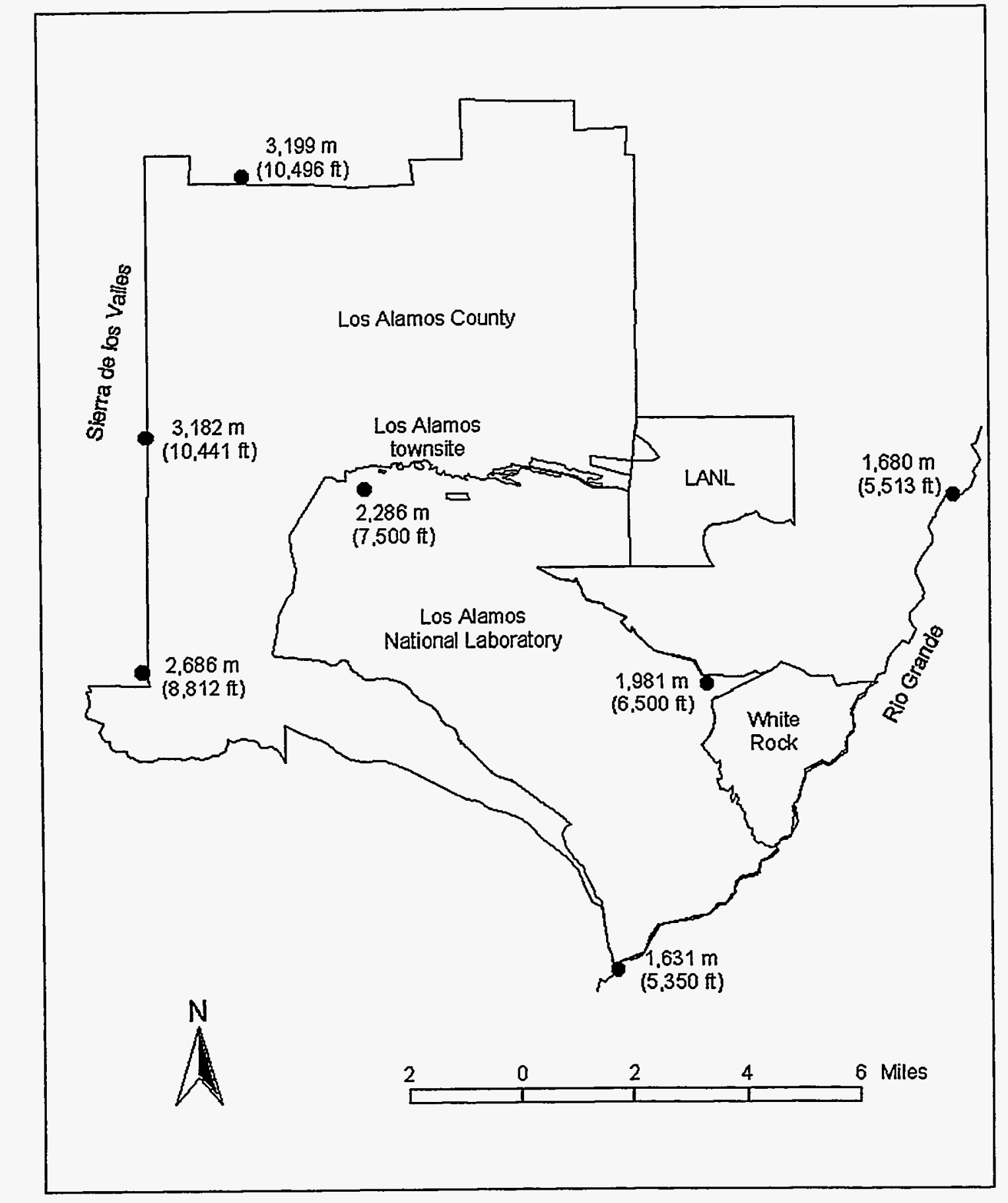

Figure 2. Los Alamos County and Los Alamos National Laboratory. 


\subsection{Geologic setting}

The Sierra de los Valles is a semicircular mountain chain that forms the easternmost portions of the Jemez Mountains. Geologically, the Sierra is largely a remnant of the rim of an ancient caldera (Kelly 1978, Nyhan et al. 1978). The underlying bedrock of the Sierras, the Tschicoma Formation, resulted from Tertiary volcanic flows and eruptions. Initially, these deposits grew into a large volcano. But two major eruptions, which occurred between 1.1 and 1.4 million years ago, destroyed all but the rim of this volcano. Much of the ejected pumice and rhyolite ash was deposited immediately to the east of the volcano, forming the Bandelier tuff and the Pajarito Plateau. Subsequent erosion has dissected the Pajarito Plateau into mesas, separated by canyons. These canyons are lined with alluvial deposits of Bandelier Tuff and Tschicoma materials.

\subsection{Climatic setting}

The climate of the study area and the surrounding region is influenced by topographic conditions (Bowen 1990). At low elevations in the study area, about $2,225 \mathrm{~m}(7,300 \mathrm{ft})$, the frost-free period is approximately 120 days. In contrast, above $3,048 \mathrm{~m}(10,000 \mathrm{ft})$ frosts can occur during any month of the year.

The annual precipitation levels also show the effect of changing elevations (Bowen 1990). At the Los Alamos townsite, precipitation levels reach nearly $46 \mathrm{~cm}$ (18 in.) per year. At highest elevations in the Sierra de los Valles, the annual precipitation averages $76 \mathrm{~cm}$ (30 in.) or more. Regardless of the elevation, most of the precipitation is received during the summer months. During the winter months, the predominant form of the precipitation is snow. The annual snow depths at the higher elevations may exceed 127 cm (50.0 in.).

\subsection{Methods}

The results described in this report are part of a larger effort to characterize the fuel loads and vegetational structures in forests of the Los Alamos region and to assess the fire hazards that they represent. As such, many of the field methods were tailored to meet the needs of fuels inventories and fire behavior analyses. The methods and results outlined in this report will emphasize those that pertain to the description and characterization of vegetation.

\subsection{Sample site selection}

Several geographic information system (GIS) data layers, including digital terrain models, were assembled and combined with a Landsat Thematic Mapper (TM) image of the study area. A previously developed land cover map was also incorporated into this system of GIS data layers (Koch et al. 1997). The predominant vegetation types in the study area include ponderosa pine forests, mixed conifer forests, aspen forests, and grasslands (Figure 3). In Figure 3, both mixed conifer and spruce-fir forests are 


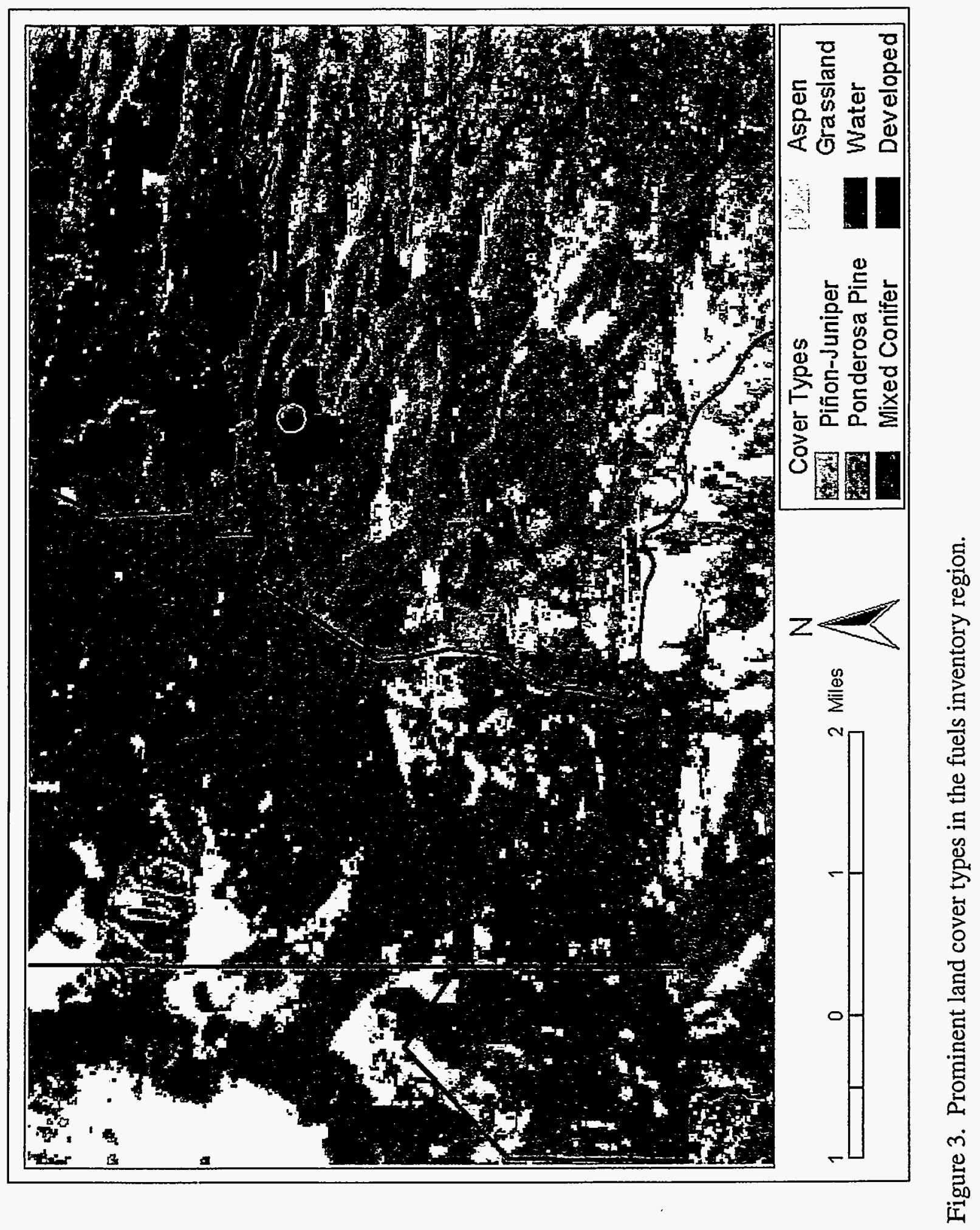


represented by a single class. These sources of information were grouped by an unsupervised routine into 12 topographic-vegetation clusters. Then, 10 sites were randomly selected from each cluster.

\subsection{Plot location and plot delineation}

The general locations of a subjective subsample of these sample sites were located on the ground with the assistance of a Garmin global positioning system (GPS) receiver. The general area of each plot was checked to verify the homogeneity of the vegetation and topographic conditions. Moreover, to be retained during this selection process, the sites were initially required to be at least $90 \mathrm{~m}$ ( $295 \mathrm{ft})$ in diameter if the GPS signal was weak. However, if the GPS signal was strong and if topographic diversity of the plot location was high, then an area as small as $60 \mathrm{~m}$ by $60 \mathrm{~m}$ was accepted. Adjustments to the plot location were made as necessary to maintain consistency with the homogeneity criteria. Then, a haphazard toss of a chaining pin was used to locate the exact center of the sample site. However, sample sites that did not meet the homogeneity and minimum size criteria were rejected.

For the purposes of this study, 30 sample locations were retained and subjected to detailed sampling (Figure 4). The sampled locations ranged in elevation from approximately $2,164 \mathrm{~m}(7,100 \mathrm{ft})$ above mean sea level to nearly $3,109 \mathrm{~m}(10,200 \mathrm{ft})$.

From the plot center a square area, either $90 \mathrm{~m}$ by $90 \mathrm{~m}$ or $60 \mathrm{~m}$ by $60 \mathrm{~m}$ and oriented with the slope contours, was defined. This main plot was subdivided into nine subplots that were $30 \mathrm{~m}$ by $30 \mathrm{~m}$ each. The subplots were numbered from one through nine. The upper-left subplot was designated subplot one and the remaining plots were numbered sequentially in a clockwise direction, with the central subplot being subplot nine. The center and the four corners of subplot nine were permanently monumented with 20 penny nails.

Note that when a $60-\mathrm{m}$ by $60-\mathrm{m}$ homogeneous area was used as a plot location, the entire set of nine subplots was not designated. Instead, to accommodate this smaller sample area, only the central subplot, number nine, and the subplot that had been randomly selected were delineated.

Next, each subplot was divided into four quads. The upper-left quad was designated quad one. The remaining quads were numbered sequentially in a clockwise direction so that the lower left quad was quad four.

\subsection{Randomization and subplot selection}

Most of the data were collected from randomly selected points, within randomly selected quads, and in randomly selected subplots. However, the exact method of this randomization process was adjusted during the course of the field season to optimize issues related to the intensity of sampling within each main plot and the need for extensiveness of main plot sampling. Early in the season, two subplots, in addition to 
subplot number nine, were randomly selected. Within these subplots, two quads were randomly selected. Within each quad, random starting points along the lower boundary of the quad were used to delineate line transects for sampling of all understory and soils parameters. At a later date, this sampling intensity was reduced from two randomly selected subplots to one subplot, and from two randomly selected quads to one quad. In addition, the method of sampling along the randomly selected line transects was also slightly modified. In the following discussion of methods, generic descriptions of the subplot sampling are given. Wherever necessary, notes are included to distinguish between the intensive and extensive methods.

\subsection{Site information}

After the plot and the subplots were delineated, general site information was recorded. This included directions to the plot from the nearest major landmark, general comments of the vegetation structures and species compositions, soils, topographic position, disturbance history, fire hazards, nearby features, and disease. The general fuel model for the site was also noted (Anderson 1982). The location of the plot center was recorded with a Trimble GPS unit. When a camera was available, photographs of the plot were taken. The margin of error for the plot layout procedure was also recorded.

Some of the site information was recorded within each quad. This included slope, aspect, elevation, horizontal configuration, and vertical configuration. From this information within each quad, overall averages were calculated for the plot.

\subsection{Overstory structures}

Within each randomly selected quad and all quads within subplot number nine, all trees greater than $10 \mathrm{ft}$ tall were recorded by species and diameter at breast height (DBH). Additionally, a full suite of descriptive data was recorded for each tree in the randomly selected quad within subplot number nine. In addition to species and DBH, this included the presence of multiple stems, live or dead status, total height, height to the base of the continuous crown, largest crown width, overall crown shape, and the mistletoe rating. Crown shapes were classified as a rectangle, circle, triangle, inverse triangle, or diamond.

If mistletoe was present, a 6-class rating system was used to characterize the infestation. First, the tree crown was ocularly divided into thirds. Second, each of the three crown sections. were rated 1) as zero if there were no visible mistletoe infestations, 2) one if the infestation was limited to not more than one-half of the branches, and 3) two if the infestation was present in greater than one-half of the branches. Third, the three ratings were added and recorded for the tree.

The percent overstory crown closure was also measured with a spherical densiometer. This was done at the center and the four corners of subplot number nine. At each of these stations, the percent crown closure was measured in the four axes of the plot boundaries. Then an overall average of percent crown closure was calculated from these individual measurements. 


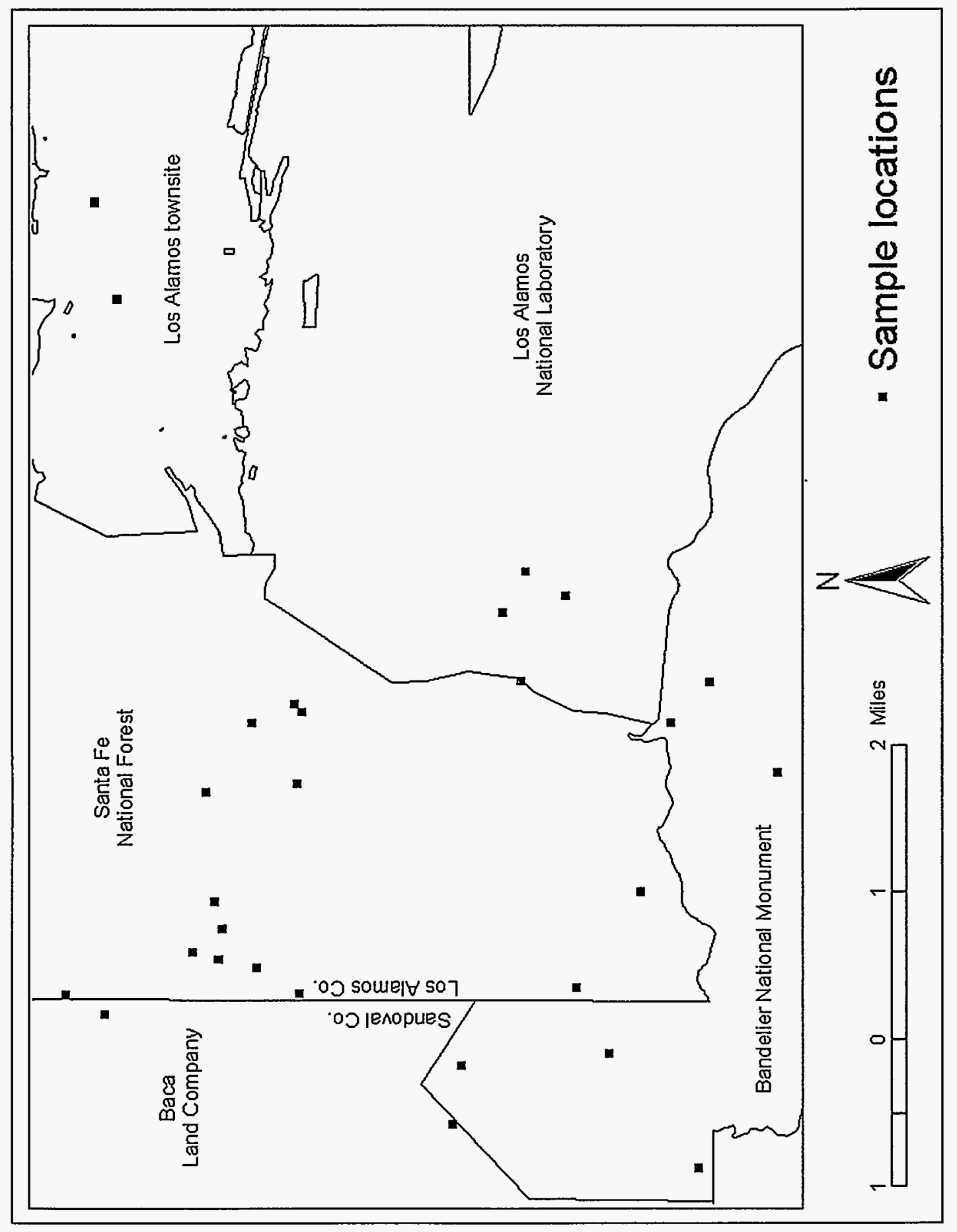

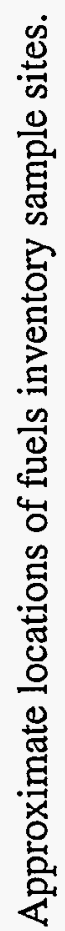

市 



\subsection{Understory sampling}

Within each randomly selected quad, a random start was defined along the lower boundary where the lower left corner of the quad was defined as the starting point. From this random start, a 15-m line transect was constructed to the identical point on the upper boundary of the quad. A second $15-\mathrm{m}$ line transect was constructed in a parallel position, but located an additional $2 \mathrm{~m}$ from the first transect. Forbs, small shrubs, and soils were sampled along the first transect. Down woody fuels, duff, and fuels biomass were sampled along the second transect. Shrubs and small trees were sampled in the 2-m by $15-\mathrm{m}$ strip between the two transects.

During the intensive phase of sampling at the beginning of the field season, two quads were randomly selected in each of the randomly selected subplots. In addition, two quads were randomly selected in subplot number nine, the central subplot. This resulted in six random replications of the understory sampling procedure within each plot. To allow for more extensive sampling throughout the study area, the within-plot sampling intensity was reduced to a single randomly selected quad in the central subplot and a single randomly selected quad in one additional randomly selected subplot. This reduced the amount of overstory sampling to a satisfactory level, but severely limited the amount of understory sampling. To alleviate this problem, the understory transects and strips were extended in both directions from their respective random starting points. This modification resulted in a total of two $30-\mathrm{m}$ line transects per plot for sampling vegetation and fuels, and two $2-\mathrm{m}$ by $30-\mathrm{m}$ strip transects per plot for sampling shrubs and small trees.

Along the first transect, each graminoid, herbaceous, and shrubby plant or canopy of plants was recorded by species and by the amount of intercept, to the nearest centimeter. Shrub samples were limited to those shrubs less than two feet tall. The amount of intercept by litter, bare soil, moss, gravel, cobbles, stones, boulders, and bedrock was also recorded, to the nearest centimeter. When this was complete, a census of the species present in the quad was recorded. In addition, a soil pit was dug in the randomly selected quad within subplot number nine. From this soil pit, the soil was described.

Down woody fuels and related parameters were sampled along the second transect (Brown 1974, Brown et al. 1982). From the initial point on the lower boundary, 1-hour fuels and 10-hour fuels were measured for the first $2 \mathrm{~m}, 100$-hour fuels were measured for the first $3 \mathrm{~m}$, and 1000-hour fuels were measured along the entire 15-m length of the transect. In addition, the duff depth, to the nearest centimeter, was measured at $2 \mathrm{~m}$ and at $6 \mathrm{~m}$ from the starting point.

Litter biomass and vegetation biomass samples were also collected along these transects for later weighing, drying, and re-weighing. These data were used to calculate the amount of understory fuels.

Shrubs greater than two feet tall and trees less than ten feet tall were sampled in the 2-m by $15-\mathrm{m}$ strip transects. These were recorded by species and by basal diameter. For 
multiple-stemmed individuals, the number of stems by size class was also recorded. In addition to species and basal diameter, live or dead status, total height, height to the base of the continuous crown, largest crown width, and overall crown shape were also recorded. Crown shapes were classified as a rectangle, circle, triangle, inverse triangle, or diamond.

\subsection{Office methods}

All of the field data were entered into spreadsheet files. Then, the data pertaining to plant communities and environmental relationships were summarized by subplot and by plot. For the purposes of this report, the summarized vegetation data, topographic, soils, and site information and all related data were qualitatively evaluated by table rearrangement methods. The plots were grouped into those with similar vegetation, soils, and topographic characteristics. The resulting groups were compared with vegetation classification previously developed for the Los Alamos region (Balice et al. 1977). The results were also contrasted with those representing similar environments in New Mexico, Arizona, Colorado, and Utah. Finally, a dichotomous key that had been previously designed to identify the groups of plant communities in the field was modified and updated to incorporate this new information.

\subsection{Results}

The descriptive results of this survey are listed in the following section. The plant species mentioned in the text are indexed by common name in Appendix $\mathrm{A}$ and by scientific name in Appendix B. The dichotomous key to the major land cover types in the Los Alamos region is provided in Appendix C.

\subsection{Ponderosa pine forests}

Ponderosa pine forests extend to as low as $1,921 \mathrm{~m}(6,300 \mathrm{ft})$ in canyons and to as high as $2,652 \mathrm{~m}(8,700 \mathrm{ft})$ on mesas and lower slopes of the Sierra. Ponderosa pine forests are the most abundant forests on the mesas and canyons of the Pajarito Plateau, but become uncommon in the Sierra de los Valles.

Ponderosa pine (Pinus ponderosa) is the dominant species, and perhaps the only species, in the overstory of ponderosa pine forests. Succession would typically follow a simple pathway from grasslands to shrublands to ponderosa pine forests. Significant quantities of Douglas fir (Pseudotsuga menziesii) or white fir (Abies concolor) may also be present, but this would indicate that ponderosa pine is only a temporary forest type at these sites and would eventually be replaced by these more shade tolerant species. Piñon (Pinus edulis), one-seed juniper (Juniperus monosperma), Rocky Mountain juniper (Juniperus scopulorum), and limber pine (Pinus flexilis) may also be present, but never in large quantities. 


\subsubsection{Ponderosa pine (Pinus ponderosa)/Gambel oak (Ouercus gambelii)}

This is the most common community type in the ponderosa pine zone. It is also well represented throughout New Mexico and southern Colorado (Alexander et al. 1984, DeVelice et al. 1986). In the Los Alamos region, the ponderosa pine/Gambel oak community type can be found from $2,024 \mathrm{~m}(6,640 \mathrm{ft})$ on north-facing topographic positions to as high as $2,652 \mathrm{~m}(8,700 \mathrm{ft})$ on east-facing and south-facing exposures. Between $2,073 \mathrm{~m}(6,800 \mathrm{ft})$ and $2,362 \mathrm{~m}(7,750 \mathrm{ft})$, ponderosa pine/Gambel oak is the dominant community type of relatively flat, mesa environments.

Ponderosa pine is typically the only tree species in the overstory. Piñon and one-seed juniper are present in varying amounts and may be common at lower elevations. At higher elevations within this community type, Rocky Mountain juniper, limber pine, Douglas fir, and white fir may also occur as scattered individuals.

The successional status of ponderosa pine/Gambel oak varies according to the elevations at which these communities are found. At lower and middle elevations, ponderosa pine will persist indefinitely unless disturbed. However at the upper limits of this community type, ponderosa pine will eventually be replaced by Douglas fir or white fir if succession is allowed to proceed.

Gambel oak (Quercus gambelii) is always present in the understory and is frequently the only shrub species present. However, in closed-canopied forests, Gambel oak may be present in low quantities only (see also Hanks et al. 1983). At low elevations within this community type, skunkbush (Rhus trilobata), Apache plume (Fallugia paradoxa), narrowleaf hoptree (Ptelea trifoliata), and bitterweed (Hymenoxys richardsonii) may coexist with the Gambel oak, while at higher elevations, New Mexico locust (Robinia neomexicana), Colorado barberry (Berberis fendleri), and Wood's rose (Rosa woodsii) are more common. Mountain mahogany (Cercocarpus montanus) is commonly found at all elevations.

Understories in ponderosa pine/Gambel oak are typically sparse. Most of the ground cover consists of needle litter. However, a variety of species do occur. For instance graminoids, such as blue grama (Bouteloua gacilis), White Mountain sedge (Carex geophila), muttongrass (Poa fendleriana), June grass (Koeleria macrantha), mountain muhly (Muhlenbergia montana), little bluestem (Schizachyrium scoparium), pine dropseed (Blepharoneuron tricholepis), and bottlebrush squirreltail (Sitanion hystrix) may be found. Of these, White Mountain sedge is the only graminoid that is both frequent and common. Forbs, such as Wooton's senecio (Senecio wootonii), pussytoes (Antennaria parvifolia), perky Sue (Hymenoxys argentea), golden pea (Thermopsis pinetorum), woodland strawberry (Fragaria vesca), purple geranium (Geranium caespitosum), yarrow (Achillea millefolium), and mountain parsley (Pseudocympoterus montanus), also occur frequently but on low overall quantities. Pincushion cactus (Coryphantha vivipara) and purple fruit prickly pear (Opuntia phaeacantha) are common representatives of the cactus family. The predominant fuel type is fuel model 9. 
Soils of the ponderosa pine/Gambel oak community type are rather deep and lack obvious stoniness or exposed bedrock. As the rockiness of the soil increases, shrubs and graminoids other than Gambel oak and White Mountain sedge become more prominent. Eventually, the Gambel oak understory union is replaced by the Mountain muhly understory complex as the lithic component of the soil surpasses limits that are critical for these species.

The ponderosa pine/Gambel oak community type is extremely variable (De Velice et al. 1986; see also Hanks et al. 1983, Alexander et al. 1987). Further studies may warrant the delineation of phases within this community type or the recognition of separate community types.

\subsubsection{Ponderosa pine (Pinus ponderosa)/Mountain muhly (Muhlenbergia montana)}

Ponderosa pine is typically the only tree in the overstory of this community type. Oneseed juniper, Douglas fir, and limber pine may also occur as scattered individuals. Occasionally, Douglas fir may be present in sufficient quantities to suggest that succession may eventually lead to the dominance of this species. However, closer examination will reveal that these individuals occupy relatively deep-soil microsites in otherwise harsh, shallow-soil environments.

The total cover of shrubs and forbs in the ponderosa pine/mountain muhly community type is low. Gambel oak may be present in small amounts, typically less than 5 percent cover. However, cliffbush (Jamesia americana), kinnikinnik (Arctostaphylos uva-ursi), Colorado barberry, and mountain mahogany may equal or surpass the abundance of Gambel oak. Mountain muhly is present in the understory and may be dominant. Other grass species are also typically present and are considered diagnostic of this cover type. These include June grass, pine dropseed, little bluestem, muttongrass, and bottlebrush squirreltail. Forbs are uncommon. Among these, Wooton's senecio, golden pea and perky Sue are representative. The predominant fuel type is fuel model 9.

Examples of the ponderosa pine/mountain muhly community type are found on gently sloping mesas above $2,134 \mathrm{~m}(7,000 \mathrm{ft})$ where it forms a mosaic with ponderosa pine/Gambel oak (DeVelice et al. 1986). As sites become more xeric at lower elevations, this community type intergrades with ponderosa pine/blue grama. Throughout its range, ponderosa pine/mountain muhly occupies sites with thin soils and much exposed bedrock. Because of the inhospitable soils, site productivity is low. Trees grow rather slowly, are widely spaced, and do not achieve great heights. These diagnostic stand structures are significant, however, because they form natural fire breaks which may be useful from the standpoint of fire management and fire suppression.

Within northern New Mexico, the Jemez Mountains mark the southern limits of ponderosa pine/mountain muhly (DeVelice et al. 1986). This cover type is mostly found in the San Juan Mountains of New Mexico and, occasionally, in the Sangre de Cristo Mountains. 


\subsection{Mixed conifer forests}

Mixed conifer forests replace ponderosa pine forests as elevations increase in the Sierra and as sites become more protected from insolation. Douglas fir or white fir are the dominant overstory species, although a wide variety of tree species may also be present in the overstory or midstory.

Mixed conifer forests begin as intergrades with ponderosa pine communities and as stringers on north aspects of the canyons and on the canyon bottoms above 2,104 m $(6,900 \mathrm{ft}$ ) in elevation (Foxx and Tierney 1980, Figure 3$)$. These communities continue to $2,591 \mathrm{~m}(8,500 \mathrm{ft})$ on eastern exposures and on flat areas. On southern exposures, mixed conifer forests extend to $2,957 \mathrm{~m}(9,700 \mathrm{ft})$. The mean annual precipitation ranges from 51 to $76 \mathrm{~cm}$ ( 20 to $30 \mathrm{in}$.).

From a dominance standpoint, mixed conifer forests can be divided into two cover types: Douglas fir forests and white fir forests. Except at the lowest elevations in the fir forest zone, the Douglas fir cover types are seral elements of the white fir community type. Therefore, if succession is allowed to proceed, white fir forests will become more common and Douglas fir forests will be limited to a relatively narrow band above the ponderosa pine forests that is too dry for white fir establishment.

The overstories in the mixed conifer zone are highly variable and can contain a variety of tree species in varying proportions. The species compositions in the shrub and forb layers are also complex. Together, this variation is indicative of the complex environmental and successional relationships of these forests. Overstory structures indicate the overall climatic conditions that allow differential establishment of trees, while the species compositions of the understory respond to soils and topographic influences (Daubenmire 1968). For instance, Gambel oak occurs in greater amounts on comparatively dry sites, while whortleberry (Vaccinium myrtillus) is found on cold sites.

Douglas fir has the greatest ecological amplitude of any coniferous species in northern New Mexico (DeVelice et al.1986, Peet 1988). This is attributed to the substantial genetic variation among the Douglas fir populations from contrasting habitats (Rehfeldt 1974). In the Los Alamos study region, this is reflected in the broad elevational distribution of Douglas fir. This species can be found as low as $1,981 \mathrm{~m}(6,500 \mathrm{ft})$ in protected canyons of the Pajarito Plateau and as high as $3,048 \mathrm{~m}(10,000 \mathrm{ft})$ on Pajarito Mountain. However, Douglas fir is less shade tolerant than white fir and is seral in stands where the two species exist.

At suitably moist sites within mixed conifer forests, inclusions of montane meadow vegetation are supported (Potter and Foxx 1981). These meadows support a wide variety of grasses, sedges, and forbs, but only a few shrub species. Montane meadows are important wildlife habitat areas. 


\subsubsection{Douglas fir (Pseudotsuga menziesii)/Gambel oak (Quercus gambelii)}

Douglas fir/Gambel oak communities can be found from 2,104 m (6,900 ft) to 2,591 m $(8,500 \mathrm{ft})$. Below 2,286 m (7,500 ft) Douglas fir/Gambel oak occupies steeply-sloping, north-facing positions in the canyons that dissect the Pajarito Plateau. Above this elevation, it is found on moderate to steep slopes with east or southeast aspects. The ground surface at these high-elevation sites can be quite rocky (Alexander et al. 1984).

In this cover type, Douglas fir is dominant in the overstory or present in significant quantities in the midstory. However, ponderosa pine is nearly always a codominant or dominant species. The ponderosa pine trees are frequently infected with dwarf mistletoe (Arceuthobium vaginatum). Limber pine and aspen (Populus tremuloides) may also be present in the overstory, while one-seed juniper, piñon, and white fir frequently occur in the midstories and understories as scattered individuals.

Undergrowths of Douglas fir/Gambel oak are highly variable, but always support Gambel oak in significant quantities. Other tall shrubs that are frequent in this cover type include New Mexico locust, Woods' rose, oceanspray (Holodiscus dumosus), cliffbush, Colorado barberry, and mountain mahogany. Fendlerbush (Fendlera rupicola) may also be found in small quantities. In the low shrub stratum, kinnikinnik, Oregon grape (Berberis repens), Woods' rose, wax currant (Ribes cereum), and myrtle boxleaf (Pachystima myrsinites) are the most frequent species. Among the most common forbs, pussytoes, Wooton's senecio, woodland strawberry, yarrow, and mountain parsley are notable. White Mountain sedge is typically present in significant amounts. Other common graminoids include June grass, fringed brome (Bromus ciliatus), muttongrass, bottlebrush squirreltail, and mountain muhly. The predominant fuel type is fuel model 9.

Douglas fir/Gambel oak is commonly found in a narrow elevational zone within the mixed conifer forest zone and may be considered to be an ecotone between the warmer pine forests and the cooler mixed conifer forests (Alexander et al. 1984). In the Los Alamos region, Douglas fir/Gambel oak is bounded by ponderosa pine/Gambel oak at lower elevations and white fir/Gambel oak at higher elevations.

\subsubsection{White fir (Abies concolor)/Gambel oak (Ouercus gambelii)}

This cover type occurs throughout the southern Rocky Mountains (DeVelice et al. 1986). It is also widespread in the Los Alamos study region between 2,438 and $2,957 \mathrm{~m}(8,000$ and $9,700 \mathrm{ft}$ ). Slopes range from gentle to very steep. East-facing and south-facing aspects predominate. Soils are typically deep and loamy but may include significant amounts of stones and cobbles.

White fir dominates the overstory, often with nearly equal amounts of Douglas fir and ponderosa pine. There may also be significant numbers of limber pine and aspen.

The understories of white fir/Gambel oak are highly variable and diverse. Gambel oak is the dominant component of the shrub layer. Cliffbush is also common. Typical 
examples of lower growing shrubs include Oregon grape, Colorado barberry, kinnikinnik, wax currant, New Mexico locust, whitestem gooseberry (Ribes inerme), myrtle boxleaf, Fendler rose, and mountain snowberry (Symphoricarpos oreophilus). Graminoids are not as well represented as in some of the cover types at lower elevations. However, White Mountain sedge, mountain muhly, fringed brome, junegrass, and muttongrass are representative. The number of forb species represented is usually high, although the overall forb coverage is typically low. Pussytoes, woodland strawberry, Louisiana wormwood (Artemisia ludoviciana), Wooten's senecio, mountain parsley, Arizona peavine (Lathyrus arizonicus), yarrow, Fendler meadowrue (Thalictrum fendleri), and purple geranium are representative. The predominant fuel type is fuel model 9.

Fire is an important ecological component in white fir/Gambel oak forests (DeVelice et al. 1986). The high coverage of Gambel oak may reflect the abilities of this species to reproduce vegetatively after fire, after which this species may dominate a site for some time. These conditions result in valuable browse and cover for deer and elk.

\subsubsection{White fir (Abies concolor)/Kinnikinnik (Arctostaphylos uva-ursi)}

This cover type is found on exposed ridgelines between $2,469 \mathrm{~m}(8,100 \mathrm{ft})$ and $2,591 \mathrm{~m}$ $(8,500 \mathrm{ft})$. Slopes are less than 10 percent. Aspects tend toward the south. The bedrock in these sites is close to the surface, with the result that the soils are thin. Consequently, site productivity is low, and disease and mistletoe are prominent. Due to the overall low productivity of these sites, the growth rates of the vegetation may vary significantly with relative wetness and dryness of the annual weather cycles.

The overstories of white fir/kinnikinnik communities may be dominated by dense stands of depauperate ponderosa pine. Moderate amounts of limber pine may also be present. However, significant quantities of Douglas fir and white fir indicate that succession would ultimately favor these more shade tolerant species. Low site productivity makes succession an extremely slow process. The ponderosa pine trees are typically heavily infested with dwarf mistletoe.

Gambel oak may be present in the shrub layer in significant quantities. However, the prominence of the low shrub, kinnikinnik, betrays the relatively xeric nature of these sites. Overall diversity in the understory of white fir/kinnikinnik is low. In addition to Gambel oak and kinnikinnik, wax currant may also be present. White Mountain sedge may the only other species that is common. Additional species may include scattered individuals of woodland strawberry and mountain mubly. The predominant fuel type is fuel model 9.

White fir/kinnikinnik represents a cool, dry environment (DeVelice et al. 1986). Snow accumulation is low. As a result, this community type may be best suited as winter range for wildlife. 


\subsubsection{White fir (Abies concolor)/Mountain maple (Acer glabrum)}

This cover type occurs throughout the mountains of southern Colorado and northern New Mexico (DeVelice et al. 1986). In the Los Alamos study region, it is found on mid-slope and lower-slope positions and along drainages in the mountains. Elevations range from $2,438 \mathrm{~m}(8,000 \mathrm{ft})$ to $2,804 \mathrm{~m}(9,200 \mathrm{ft})$. All aspects are represented, although this community type typically occurs on north exposures where stones, boulders, and bedrock are close to the surface.

The forest overstories in white fir/mountain maple are highly complex (DeVelice et al. 1986). White fir is dominant, often with Douglas fir as a codominant. Limber pine, aspen, and ponderosa pine may also be present in relatively large numbers. Engelmann spruce (Picea engelmannii) may appear in frost pockets.

The white fir/mountain maple cover type is rich in shrub species. The presence of significant quantities of mountain maple (Acer glabrum) is diagnostic. In addition, Utah serviceberry (Amelanchier utahensis), ninebark (Physocarpus monogynous), chokecherry (Prunus virginiana), cliffbush, and mockorange (Philadelphus microphyllus) may be present as medium and tall shrubs. Gambel oak and New Mexico locust may also be present. In addition, Oregon grape, whortleberry, whitestem gooseberry, thimbleberry (Rubus parviflorus), myrtle boxleaf, and mountain snowberry are typical occupants of the low shrub stratum. The predominant fuel type is fuel model 10 .

Forbs are also well represented in the white fir/mountain maple cover type. These include false Solomon's seal (Smilacina racemosa), Virginia strawberry (Fragaria virginiana), Canadian violet (Viola canadensis), bedstraw (Galium aparine), rattlesnake plantain (Goodyera oblongifolia), pussytoes, Fendler meadowrue, sweet cicely (Osmorhiza obtusa), and Rocky Mountain clematis (Clematis pseudoalpina). Although graminoids are not in abundance, western sedge (Carex occidentalis), fringed brome, nodding brome (Bromus anomalus), and mountain muhly are usually represented.

White fir/mountain maple occurs in sites that combine cool, north-facing environments with thin, bouldery soils. The lithic soil structures impede overstory productivity. Moreover, because this cover type tends to occur on more protected sites, there is less of a tendency for high-intensity fires to occur (Moir and Ludwig 1979, DeVelice et al. 1986). When fires do occur they burn patches of forest. Thus, the overstory structures in white fir/mountain maple may be quite variable from place to place.

Riparian vegetation occurs in the drainages and lower-slope positions in the mixed conifer zone (Foxx and Tierney 1984). The overstory compositions are similar to the White fir/mountain maple community type. However, the understory vegetation reflects the additional soil moisture that is available to plants in these areas. Scouler willow (Salix scouleriana) is present in the shrub layer. Diagnostic forb species include Arizona valerian (Valeriana arizonica), dog violet (Viola adunca), and bracken fern (Pteridium aquilinum). Further evaluations may support the separation of these vegetation assemblages as distinct riparian communities 


\subsubsection{White fir (Abies concolor)/Forest fleabane (Erigeron eximius)}

This community type is common in the Jemez Mountains, but rare elsewhere (DeVelice et al. 1986). In our area, it occupies relatively mesic, mid-slope, and upper-slope positions. All aspects are represented, but north-facing aspects with deeper, less rocky soils are most abundant. The elevations of this community type range from $2,560 \mathrm{~m}$ $(8,400 \mathrm{ft})$ to $2,819 \mathrm{~m}(9,250 \mathrm{ft})$.

The overstories of white fir/forest fleabane are highly complex (DeVelice et al. 1986). White fir is always present in abundance. However, Douglas fir is often a codominant species. Limber pine and ponderosa pine are also typically present in varying amounts. Aspen may also be abundant in areas that have recently burned.

In contrast to the white fir/mountain maple community type, shrubs are not as common in white fir/forest fleabane communities. A variety of shrub species, such as dwarf juniper (Juniperus communis), myrtle boxleaf, whitestem gooseberry, and New Mexico locust, may be present in small quantities. However, the bulk of the understory biomass consists of forbs and graminoids. Typical graminoids include nodding brome, fringed brome, and western sedge. Forbs include forest fleabane (Erigeron eximius), false Solomon's seal, bracken fern, purple geranium, Fendler meadowrue, bedstraw, ragweed sagebrush (Artemisia franserioides), Canadian violet, Virginia strawberry, yarrow, American vetch (Vicia americana), and Arizona peavine (Lathyrus arizonicus). The predominant fuel type is fuel model 10.

White fir/forest fleabane communities are moist and protected from extreme sun and wind (DeVelice et al. 1986). As such, they provide wildlife browse during the summer months but are inaccessible during the winter and spring months because of heavy snow accumulations.

\subsection{Aspen forests}

This cover type occurs in montane and upper montane landscape positions. Aspen is present in the overstory with at least 20 percent cover. Some combination of Douglas fir, ponderosa pine, white fir, or Engelmann spruce is also present in the overstory or the midstory.

Aspen communities are common at higher elevations in the mountains. They range in elevation from approximately 2,700 to $3,030 \mathrm{~m}$ (8,900 to 9,950 ft). Aspen stands may occupy any aspect or slope position.

Aspen is the dominant tree species in these forests, ranging from 30 percent to 85 percent overstory coverage. At higher elevations and on southerly aspects, aspen typically exceeds 45 percent coverage and may be the only species present in the overstory. In these cases, aspen may dominate the community indefinitely. At lower elevations and on northerly aspects, white fir, Engelmann spruce, and Douglas fir may collectively 
contribute up to 30 percent of the overstory coverage. At these sites, aspen will ultimately be replaced by these more shade tolerant species. Depending on the fire history of the specific stand, other tree species, such as ponderosa pine and limber pine, may be common or rare.

Aspen forests provide important habitat for wildlife, including elk, deer, ruffed grouse (Bonasa umbellus), and cavity nesting birds (DeByle and Winokur 1985). To maintain this habitat in the proper proportions to maintain healthy populations of these wildlife species, the successional status of aspen stands must be understood, and appropriate management for the maintenance of these aspen stands must be designed and implemented.

\subsubsection{Aspen (Populus tremuloides)/Bracken fern (Pteridium aquilinum)}

This community type was reported during earlier research activities in the Los Alamos area, although it was not encountered during the current survey. It has been identified in Utah (Mueggler and Campbell 1986, Mueggler 1988). It has also been recognized throughout western Colorado where it occupies deep, loamy soils and poorly drained sites (Hoffman and Alexander 1980, 1983, Komarkova et al. 1988). The vegetational structures reported for the Los Alamos region are similar to those documented in Utah and Colorado.

Aspen/bracken fern communities occur at high elevations and on south-facing slopes. They are characterized by their overall lack of coniferous tree species in the overstory and by densely herbaceous understories. Although white fir, Douglas fir, or Engelmann spruce may be present in small quantities, it has been suggested aspen may be selfperpetuating (Hoffman and Alexander 1980, 1983). However, the successional status of these forests is in question (Mueggler 1988).

Understories in aspen forests are well developed. Fringed brome, mountain brome (Bromus marginatus), and slender wheatgrass (Agropyron trachycaulum) are the most common graminoid species, along with lesser amounts of timber oatgrass (Danthonia intermedia) and bluegrass (Poa spp.). A wide variety of shrubs and forbs may be present. In addition to bracken fern, a typical species list of common forbs might also include woodland strawberry, bedstraw, false Solomon's seal, American vetch, Arizona peavine, and Fendler meadowrue. Shrubs, such as Gambel oak, New Mexico locust, chokecherry, Woods' rose, and cliffbush, may also be present.

\subsubsection{Aspen (Populus tremuloides)/Nodding brome (Bromus anomalus)}

This is a highly variable community type that is found above $2,926 \mathrm{~m}(9,600 \mathrm{ft})$, on south exposures and occupies positions in the landscape that are between montane grasslands and mixed conifer or spruce-fir forests. Aspen is the dominant overstory species with only small amounts of Douglas fir, white fir, or Engelmann spruce.

Understory of aspen/nodding brome communities are diverse and variable from place to place. Woods' rose is the most common shrub, but canopy coverage of any shrub species 
never exceeds 1 percent. The most common forbs include yarrow, Virginia strawberry, purple geranium, Rocky Mountain iris (Iris missouriensis), Arizona peavine, star flower (Smilacina stellata), and American vetch. A variety of graminoids typically exceed 1 percent cover, including nodding brome, western sedge, Thurber fescue (Festuca thurberi), muttongrass, and Kentucky bluegrass (Poa pratensis). The canopy cover of nodding brome averages 14 percent. The predominant fuel type is fuel model 2 .

The ecological relationships of this community type are poorly understood. However, aspen/nodding brome is probably transitional between montane grassland communities and mixed conifer or spruce-fir forests. This is evidenced by the apparent intermediate soil depths and soil rockiness of aspen/nodding brome. The soils of montane grasslands tend to be thin and excessively rocky. On the other hand, soils of well-developed mixed conifer and spruce-fir forests are greater than $50 \mathrm{~cm}$ deep and devoid of excessive rockiness. Aspen/nodding brome soils are intermediate between these two extremes. This may allow for the perpetuation of aspen and the exclusion of conifer regeneration.

The structures and locations of aspen/nodding brome are also probably influenced by fire histories. Presumably, fires were once common occurrences in the adjacent montane grasslands (Allen 1989). These grassland fires would have spread into the adjacent aspen and conifer forests. This would have killed small trees and shrubs that do not sprout after fire. The result would have been an open forest structure with grassy and herbaceous understories. It is interesting to note, however, that these forest structures have persisted even though fires have been excluded during much of the twentieth century. This is further evidence that soil structures are partially precluding the establishment of conifers.

Although the species compositions of aspen/nodding brome are highly variable, they contain components of aspen communities recognized elsewhere. For instance, Komarkova et al. (1988) and Mueggler (1988) describe aspen/Thurber fescue and aspen/Fendler meadowrue, which are considered to be stable community types and are floristically similar to aspen/nodding brome. Unfortunately, guidance from vegetation studies in New Mexico cannot be obtained because aspen associations were not included (De Velice et al. 1986, Alexander et al. 1987). Further analyses of aspen forests in the Sierra will undoubtedly reveal their environmental relationships in greater detail and provide evidence for the continuation of aspen/nodding brome as a valid community type or for its segregation into separate classes.

\subsection{Spruce-fir forests}

Elements of this cover type occupy upper montane environments. Engelmann spruce is the dominant overstory species, although subalpine fir (Abies lasiocarpa) may also be codominant or reproducing in significant amounts. Other tree species, such as Douglas fir, white fir, and aspen, may also be present in the midstory or overstory.

Spruce-fir forests can be found on north aspects as low as $2,439 \mathrm{~m}(8,000 \mathrm{ft})$ and on more exposed slopes as low as 2,591 $\mathrm{m}(8,500 \mathrm{ft}$ ) in the Sierra de los Valles (Foxx and Tierney 1984). These communities continue to the highest elevations in the study area $(3,138 \mathrm{~m}$, 
$10,441 \mathrm{ft}$ ). Engelmann spruce, subalpine fir, and Douglas fir typically share the overstory in varying amounts. However, aspen is also a major overstory species on north-facing slopes above $2,683 \mathrm{~m}(8,800 \mathrm{ft})$ that had been burned in the middle to late $1800 \mathrm{~s}$.

At lower elevations, between 2,439 and 2,896 $\mathrm{m}(8,000$ and 9,500 ft), Douglas fir commonly occurs amongst the Engelmann spruce (Alexander 1974). Below 2,743 m $(9,000 \mathrm{ft})$, Douglas fir is presumed to be the potential climax species. Above this elevation, Engelmann spruce will replace the Douglas fir through time.

Spruce-fir forests are widely distributed throughout the highest elevations in northern New Mexico (DeVelice et al. 1986, Peet 1988). However, since these forests are near their southern limits in this region, they occupy sites above $2,591 \mathrm{~m}(8,500 \mathrm{ft})$ with fairly localized environmental conditions (Alexander 1974). Typically, they are restricted to the coldest environments: steep, north-facing slopes, protected frost pockets, and the highest elevations.

Subalpine fir and Engelmann spruce are considered to be codominant tree species in the spruce-fir forests (Alexander 1974, Moir and Ludwig 1979, Peet 1988). Where they are found together, the relative amounts of these species vary with respect to relative positions on the elevational gradient and with other factors relating to their longevities. Subalpine fir is not as frost tolerant as spruce (Minore 1979). However, subalpine fir is the more shade tolerant of the two species, and Engelmann spruce is susceptible to spruce beetles. Therefore, the relative amounts of these two species will vary as a function of the environmental conditions and the stand history.

Engelmann spruce and subalpine fir are both susceptible to fire, and intense fires can result in drastic changes to the vegetation structure (Moir and Ludwig 1979). Standreplacing fires will result in temporary communities of Douglas fir, aspen, or various grass species. The dominant species of these communities will depend on the intensity of the fire, topographic conditions, and the compositions of the previous stands. Succession from grasslands to spruce-fir communities may require up to 300 years. In contrast, where grasslands occur at higher elevations, on south-facing slopes, and on stony or rocky soils, grasslands may be self-perpetuating.

\subsubsection{Engelmann spruce (Picea engelmannii)/Moss}

Spruce-fir forests above $3,048 \mathrm{~m}(10,000 \mathrm{ft})$ and on ridgetop positions are frequently marked by low amounts of vascular plants in the understories and by high relative amounts of mosses and lichens. These unusual floristic combinations are reflected in the name of this community type, Engelmann spruce/moss. These sites are comparatively dry because of their exposure to the elements and soils that are thin, stony, and excessively drained (Moir and Ludwig 1979). The quality of these sites for tree growth is usually poor to very poor. 
The tree stratum of Engelmann spruce/moss communities usually consists solely of Engelmann spruce. White fir and Douglas fir may also be present in minor amounts. Aspen and limber pine have not been found in this community type.

The understories of Engelmann spruce/moss are characterized by their low overall coverage of vascular plants. Mosses and lichens provide most of the ground cover. Shrubs, such as mountain maple, inkberry (Lonicera involucrata), and whortleberry, are rare. Graminoids and forbs, such as sedges (Carex spp.), sidebells (Pyrola secunda), and rattlesnake plantain, may be present but never in large amounts.

This community type is rare in the Sierra and may be a reflection of the high overstory canopy coverage that reduces the potential for understory species to thrive, rather than environmental conditions. Engelmann spruce/moss has been found at the crest of Pajarito Mountain. Further investigations are required to determine if this community type is more widespread and is a valid community type in the Los Alamos region.

\subsubsection{Subalpine fir (Abies lasiocarpa)/Whortleberry (Vaccinium murtillus)}

This community type can be found on steep, north-facing slopes where soils are often thin and rocky. The elevations of these communities range from 2,865 to $3,170 \mathrm{~m}(9,400$ to $10,400 \mathrm{ft}$ ).

The overstories of subalpine fir/whortleberry communities typically consist of subalpine fir, Engelmann spruce, Douglas fir, and aspen in varying combinations. The relative amounts of these species can be highly variable from place to place. Since most of these forests have burned in the recent past, their current overstory structures are probably determined by the intensity of past fires and compositions of the previous stands (Jones 1974, Moir and Ludwig 1979). Aspen dominates in areas that have been recently burned, whereas Engelmann spruce dominates in areas where succession has been allowed to proceed. Subalpine fir is a common understory component, but occasionally shares the overstory with Engelmann spruce. The relative amounts of Douglas fir are probably dictated by previous stand compositions and by the proximity of seed sources.

The understories of subalpine fir/whortleberry are sparsely vegetated. Whortleberry and myrtle boxleaf are the only common shrub species, with canopy coverages ranging from 2 to 3 percent. Herbs are limited to less than 1 percent of ragweed sagebrush, sidebells, and rattlesnake plantain. Graminoids are rare, with only nodding brome and fringed brome being represented. The predominant fuel type is fuel model 10 .

\subsubsection{Subalpine fir (Abies lasiocarpa)/Forest fleabane (Erigeron eximius)}

In contrast to the subalpine fir/whortleberry, the name of this community type, subalpine fir/forest fleabane, reflects the relative dominance of forbs rather than shrubs. In addition, the understories are typically more lush. Subalpine fir/forest fleabane occupies the lower extremities of the spruce-fir zone, below $2,957 \mathrm{~m}(9,700 \mathrm{ft})$. When compared 
to subalpine fir/whortleberry communities, they are found on more moderate topographic positions and on soils that are deeper and less rocky.

Fires appear to have been a relatively common and severe occurrence in the subalpine fir/forest fleabane communities, when compared to the previous community type. This is indicated by the greater predominance of aspen, relative to conifers, in the overstories. Engelmann spruce and Douglas fir share dominance in the overstory. Subalpine fir and white fir share the midstories.

Shrubs are not common in this community type. Myrtle boxleaf is the most abundant shrub, averaging about 0.5 percent canopy coverage. Western baneberry (Actaea rubra) and thimbleberry may also be present in low amounts. Graminoids are also poorly represented. Conversely, forbs are represented by numerous species, including forest fleabane, Canadian violet, purple geranium, ragweed sagebrush, Arizona peavine, and star flower.

\subsubsection{Subalpine fir (Abies lasiocarpa)/Aspen (Populus tremuloides)}

In places that experienced the most severe fires, succession to subalpine fir and spruce is a slow process, and aspen may dominate the landscape for prolonged periods of time. This is common on north-facing slopes between $2,834 \mathrm{~m}(9,300 \mathrm{ft})$ and $2,987 \mathrm{~m}(9,800$ $\mathrm{ft}$ ) where spruce-fir forests are mixed with significant amounts of aspen, 12 to 20 percent cover. These are middle- to late-successional forests where spruce and subalpine fir are slowly replacing the aspen. Douglas fir and white fir may also be present in the overstory, but these species will decrease in importance with higher elevations and as succession proceeds.

Understories of these forests commonly include sidebells, star flower, rattlesnake plantain, Rocky Mountain maple, whortleberry, and myrtle boxleaf. Other species of shrubs and grasses may also be present.

\subsection{Grasslands}

The vegetation in this cover type is dominated by grasses and grass-like plant species. Forbs and other nonshrubby species may also be dominant. Shrubs are absent or present with less than 15 percent cover. Trees are also absent or present with less than 10 percent cover.

\subsubsection{Montane grassland}

At the crest of the Sierra de los Valles, montane grasslands are conspicuous components of the landscape (Dick-Peddie 1993). They occur above $2,743 \mathrm{~m}$ (9,000 ft) on steep, southerly and southwesterly facing slopes (Potter and Foxx 1981, Allen 1989). These communities occur where south-facing exposures and stony or bouldery soils create conditions that are not moist enough to support the establishment of tree species or impede the establishment of tree seedlings. The surficial cover of stones, boulders, and 
bedrock individually average 3 to 6 percent. These grassy conditions are also perpetuated by the effects from fire.

Small amounts of Douglas fir and Engelmann spruce are typically present in the montane grasslands. In the absence of fire, the quantities of these species will increase with time.

Among the graminoid species, Parry danthonia (Danthonia parryi) is the dominant species, averaging 28 percent canopy coverage. Lesser amounts of nodding brome and muttongrass are also present. Among the forbs, pussytoes, yarrow, fleabane (Erigeron spp.), mountain parsley, and woolly cinquefoil (Potentilla hippiana) are the most common, averaging 1 to 5 percent canopy coverage. The predominant fuel type is fuel model 1 or 2.

The species combinations of subalpine grasslands can be extremely variable (Potter and Foxx 1981, Allen 1989, Dick-Peddie 1993). This is controlled by the amount of lithic material in the soil and by the thickness of the solum. In areas with deeper soils, lush stands of grasses and forbs, and even shrubs and trees, are supported. On the other hand, the overall canopy coverage of plants is greatly reduced in areas with thin, rocky soils. Further studies may provide information that is sufficient to distinguish separate cover types.

\subsubsection{Montane meadow}

Within the mixed conifer zone and the spruce fir zone, meadows can often be found in relatively flat areas or in low-lying topographic positions where soils are deep and moisture collects in sufficient quantities to support dense communities of forbs and graminoids (Potter and Foxx 1981). Under such conditions, the establishment of tree species is precluded. These communities can be rather limited in area and surrounded by mixed conifer or spruce fir forests.

\section{$\underline{5.0 \text { Discussion }}$}

As a result of information gained during the 1998 field survey, revisions and updates were incorporated into specific sections of the Preliminary Key to Major Land Cover Types in the Los Alamos Region. The associated descriptions of plant community types, were also revised and updated. Specifically, seven community types variously in the ponderosa pine, mixed conifer, and aspen zones were revised. Four community types, three in the spruce-fir zone and one grassland type, were given updated names. In addition, two new community types were introduced, aspen/nodding brome and white fir/kinnikinnik, and one community type, aspen/forest fleabane, was discarded.

In spite of this new information, the cover type key and descriptions of cover types in the Los Alamos region remain in a preliminary status. The 1998 field season marks the first year that quantitative data were collected in several sections of the surveyed areas. It is also the first local attempt to relate soil characteristics to the plant communities. These 
results constitute the beginnings of a database that will ultimately provide a more comprehensive picture of the regional distributions of vegetational types and their environmental relationships. In turn, this will allow for the detailed assessment of other management values, such as wildlife habitat. However, much more extensive sampling and analyses will be required before the cover type key and descriptions can be considered final.

The gathering of descriptive, quantitative data, such as was done during the 1998 field season, is the first step in the development of more specific investigative procedures that will aid in the development of these final products (Daubenmire 1961, Mueller-Dombois and Ellenberg 1974, Gauch 1982). With respect to the 1998 field sampling, the design was based on a random sample generated by a GIS analysis. This reconnaissance approach has provided much useful and important descriptive information. In addition to continuing with randomized reconnaissance sampling, the conclusions drawn from this descriptive study will be augmented in future studies by rephrasing the current results in the form of testable hypotheses. For instance, transects of sample points could be established across the transitions from mountain grassland communities through aspen forests to the adjacent coniferous forests. This would help to understand the degree to which the distributions of these vegetational types are controlled by soil structures and topographic conditions.

The vegetation and land cover classification will also benefit from detailed and systematic studies of minor community types that are limited in size and in numbers. These types of habitat are frequently of extreme importance from a wildlife standpoint. For instance, montane meadows and their soils and topographic environments were not sampled during the 1998 field season. In addition, systematic sampling of riparian areas would also increase our understanding of this important class of communities.

A third opportunity for designing testable hypotheses can be related to Jenny's description of soil forming factors (Jenny 1961, see also Brady 1974, Buol et al. 1973). Conceptually, the formation of soils (Soil) can related to five primary factors, climate $(C l)$, parent material $(P M)$, relief $(R f)$, living organisms $(O r g)$, and time $(T)$, by the following relationship

$$
\text { Soil }=f(C l, P M, R f, \text { Org, } T) .
$$

First, climate, particularly temperature and precipitation, determines the nature of the chemical and physical processes that relate to weathering in soils. Second, specific aspects of the parent material, such as texture, structure, and chemical and minerological compositions, profoundly influence structural and chemical characteristics of soils. In turn, this is reflected in the fertility of soils. Third, relief or topographic conditions has a strong positive or negative influence on the effects of climate. Fourth, living organisms influence the properties of soils through the accumulation of organic matter, profile mixing, nutrient cycling, and by imparting structural stability. Fifth, the length of time since precursor materials of soils were exposed or deposited strongly influences the relative importance of other formation factors. For instance, the parent material and 
relief are dominant factors in formation of soils that are less than a few hundred years old. By comparison, living organisms and climate are more significant in soils that are thousands of years old.

These relationships among the factors that control soil formation can be used to evaluate the development of vegetation. Noting that organisms can be subdivided into animals $(A n)$ and vegetation (Veg), Jenny's soil formation equation can be rearranged to reflect factors that are important to the development of plant communities, as follows

$$
V e g=f(\text { Soil }, C l, P M, R f, A n, T) .
$$

With the isolation of vegetation as a dependent variable, variation amongst selected independent variables can be controlled. In this way, correlation analyses can be used to investigate the influences upon plant communities by the remaining uncontrolled variable or variables. For studies conducted in the Los Alamos region, many opportunities are available for controlling one or more of these formation factors. First, it can be assumed that the influence on soils from animals is relatively constant throughout the Los Alamos region. Second, soils on the mesas of the Pajarito Plateau are formed in residuum of the Bandelier tuff. Tuffaceous deposits also extend into the lower portions of the Sierra de los Valles. However, much of the Sierra is formed from Tschicoma parent materials. Therefore, differences between parent materials can be controlled through the careful placement of sample plot locations. Since climate and the effects of time are strongly influenced by relief in the Los Alamos region, these factors can be similarly controlled through the selection of plot locations. Further studies of vegetation in the Los Alamos region would benefit from the explicit incorporation of the "vegetation formation" model into the experimental design.

\subsection{Acknowledgments}

Grateful acknowledgment is extended to Terry Foxx, who supported this project financially through the Threatened and Endangered Species Habitat Management Planning Project. Carl Edminster, Brian Oswald, Robert Remillard and Stephen Yool also provided collaborative support through the Valle Project, funded by the Santa Fe National Forest, and through the Fire Hazard Mapping Project, funded through the U.S. Forest Service, Rocky Mountain Experiment Station.

Brian Jacobs supported this project by providing access to sample plots located on the Bandelier National Monument. Laura Trader and Kathy Bennett transferred selected GIS data files to the University of Arizona Remote Sensing Lab that were used in the construction of the random sample. Elizabeth Mozzillo and Kristen Martine assisted with issues related to the cultural resources on Bandelier National Monument and on the Santa Fe National Forest, respectively. James Stapleton and Peter Veverka provided access and escort services for the sampling of locations in S-Site. Dave Conklin, of the U.S. Forest Service Regional Office in Albuquerque, submitted the methods for rating the mistletoe 
infestations. Jay Miller offered insightful comments to the experimental and sampling design.

Numerous investigators assisted with various aspects of the fieldwork. Shelley Gardner conducted the vegetation transect sampling, analyzed the soils, and identified the unknown plant specimens. Jay Miller, with the assistance of Stephen Yool, constructed the random sample of plot locations. Jay also catalogued and summarized the GPS data, provided initial cataloging of the field data, and assisted with the fieldwork throughout much of the summer. Patrick Mitchell navigated to the selected plot locations, assisted with plot layout, dug the soil pits and conducted the sampling of the overstory vegetation, down woody fuel transects, shrub strip transects, and the vegetation and litter biomass quadrats. Suzanna Davis assisted with plot layout and with the field sampling procedures. David Martinez, Melanie Martinez, and Jennifer Tenbrink also assisted with fieldwork on an occasional basis.

Acknowledgment is also extended to those who reviewed and commented on an earlier draft of this report. These reviewers include Phil Fresquez, Hector Hinojosa, and Steve Koch. 


\subsection{Literature Cited}

Alexander, Billy G., Jr., E. Lee Fitzhugh, Frank Ronco, Jr., and John A. Ludwig. 1987. A classification of forest habitat types of the northern portion of the Cibola National Forest, New Mexico. General Technical Report RM-143, Rocky Mountain Forest and Range Experiment Station, Fort Collins, Colorado.

Alexander, Billy G., Jr., Frank Ronco, Jr., E. Lee Fitzhugh, and John A. Ludwig. 1984. A classification of forest habitat types of the Lincoln National Forest, New Mexico. General Technical Report RM-104, Rocky Mountain Forest and Range Experiment Station, Fort Collins, Colorado.

Alexander, Robert R. 1974. Silviculture of the subalpine forests in the central and southern Rocky Mountains: The status of our knowledge. Research Paper RM121, USDA Forests Service, Rocky Mountain Forest and Range Experiment Station, Fort Collins, Colorado.

Allen, Craig D. 1989. Changes in the landscape of the Jemez Mountains, New Mexico. $\mathrm{Ph} . \mathrm{D}$. dissertation, University of California at Berkeley, Berkeley, California.

Anderson, Hal E. 1982. Aids to determining fuel models for estimating fire behavior. General Technical Report INT-122, USDA Forest Service, Intermountain Forest and Range Experiment Station, Ogden Utah.

Balice, Randy G. 1990. Interactions between fungal root diseases and coniferous forest vegetation. Ph.D. Dissertation. College of Forestry, Wildlife, and Range Sciences, University of Idaho, Moscow, Idaho.

Balice, Randy G., Scott G. Ferran, and Teralene S. Foxx. 1997. Preliminary vegetation and land cover classification for the Los Alamos Region. LA-UR-97-4627, Los Alamos National Laboratory, Los Alamos, New Mexico.

Barnes, Fairley J. 1983. Habitat types in piñon-juniper woodland on the Pajarito Plateau and range conditions in Bandelier National Monument. Final report to the Southwest Region, National Park Service from the Department of Biology, New Mexico State University, Las Cruces, New Mexico.

Bowen, Brent M. 1990. Los Alamos climatology. LA-11735-MS, Los Alamos National Laboratory, Los Alamos, New Mexico.

Brady, Nyle C. 1974. The nature and properties of soils, $8^{\text {th }}$ edition. Macmillan Publishing Company, New York, New York.

Bratton, S.P. 1975. The effect of the European wild boar, Sus scrofa, on gray beech forest in the Great Smoky Mountains. Ecology 56:1356-1366. 
Brown, J.K. 1974. Handbook for inventorying downed woody material. USDA Forest Service, Intermountain Forest and Range Experiment Station, General Technical Report INT-16, Ogden, Utah.

Brown, J.K., R.D. Oberheu, C.M. Johnston. 1982. Handbook for inventorying surface fuels and biomass in the Interior West. USDA Forest Service, Intermountain Forest and Range Experiment Station, General Technical Report INT-129, Ogden, Utah.

Buol, S.W., F.D. Hole and R.J. McCracken. 1973. Soil genesis and classification. The Iowa State University Press, Ames, Iowa.

Bunce, R.G.H., S.K. Morrell, and H.E. Stel. 1975. An application of multivariate analysis to regional survey. Journal of Environmental Management 3:151-165.

Castetter, Edward F. 1956. Vegetation of New Mexico. New Mexico Quarterly, 26:256-288.

Daubenmire, Rexford. 1961. Vegetative indicators of height growth of ponderosa pine. Forest Science, 7:24-34.

Daubenmire, Rexford. 1968. Plant communities: A textbook of plant synecology. Harper and Row Publishers, New York, New York.

DeByle, Norbert V. and Robert P. Winokur (Editors). 1985. Aspen: Ecology and management in the western United States. General Technical Report RM-119, USDA Forest Service, Rocky Mountain Forest and Range Experiment Station, Fort Collins, Colorado.

DeVelice, Robert L., John A. Ludwig, William H. Moir, and Frank Ronco, Jr. 1986. A classification of forest habitat types of northern New Mexico and southern Colorado. General Technical Report RM-131, USDA Forests Service, Rocky Mountain Forest and Range Experiment Station, Fort Collins, Colorado.

Dick-Peddie, William A. 1993. New Mexico vegetation, past, present, and future. University of New Mexico Press, Albuquerque, New Mexico.

Ferguson, Dennis E., Penelope Morgan, and Frederick D. Johnson (Compilers). 1987. Proceedings-Land classifications based on vegetation: Applications for resource management. General Technical Report INT-257, USDA Forest Service, Intermountain Research Station, Ogden, Utah.

Foxx, Teralene S. 1996. Vegetation succession after the La Mesa Fire at Bandelier National Monument. Page 47-69 in Fire effects in southwestern forests, 
proceedings of the Second La Mesa Fire Symposium (Craig D. Allen, technical editor), General Technical Report RM-GTR-286, USDA Forest Service, Rocky Mountain Forest and Range Experiment Station, Fort Collins, Colorado.

Foxx, Teralene S. and Brenda Blea-Edeskuty. 1995. Wildlife use of NPDES outfalls at Los Alamos National Laboratory. LA-13009-MS, Los Alamos National Laboratory, Los Alamos, New Mexico.

Foxx, Teralene S. and Loren D. Potter. 1981. Fire ecology at Bandelier National Monument. Pages 11-37 in La Mesa Fire Symposium (Compiled by Teralene S. Foxx), LA-9236-NERP, Los Alamos National Laboratory, Los Alamos, New Mexico.

Foxx, Teralene S. and Gail D. Tierney. 1980. Status of the flora of the Los Alamos National Environmental Research Park. LA-8050-NERP, Vol I., Los Alamos Scientific Laboratory, Los Alamos, New Mexico.

Foxx, Teralene S. and Gail D. Tierney. 1984. Status of the flora of the Los Alamos National Environmental Research Park, a historical perspective. LA-8050-NERP, Volume II, Los Alamos National, Los Alamos, New Mexico.

Gauch, H.G., Jr. 1982. Multivariate analysis in community ecology. Cambridge University Press, Cambridge, England.

Hanks, Jess P., E. Lee Fitzhugh, and Sharon R. Hanks. 1983. A habitat type classification system for ponderosa pine forests of Northern Arizona. U.S.D.A. Forest Service, Rocky Mountain Forest and Range Experiment Station, General Technical Report RM-97, Fort Collins, Colorado.

Hoffman, George R. and Robert R. Alexander. 1980. Forest vegetation of the Routt National Forest in northwestern Colorado: A habitat type classification. Research Paper RM-221, Rocky Mountain Forest and Range Experiment Station, Fort Collins, Colorado.

Hoffman, George R. and Robert R. Alexander. 1983. Forest vegetation of the White River National Forest in western Colorado: A habitat type classification. Research Paper RM-249, Rocky Mountain Forest and Range Experiment Station, Fort Collins, Colorado.

Jenny, H. 1961. Derivation of state factor equations of soil and ecosystems. Soil Science Society of America Proceedings 25:385-388.

Johnson, D.W. and E.P. Odum. 1956. Breeding bird populations in relation to plant succession on the piedmont of Georgia. Ecology 37:50-62. 
Johnson, N.E., et al. 1963. Mortality and damage to Pacific silver fir by the balsam wooly aphid in southwestern Washington. Journal of Forestry 61:854-860.

Jones, John R. 1974. Silviculture of southwestern mixed conifers and aspen: The status of our knowledge. USDA Forest Service Research Paper RM-122, Rocky Mountain Forest and Range Experiment Station, Fort Collins, Colorado.

Kelly, Vincent C. 1978. Geology of Española Basin, New Mexico. Geologic Map 48, New Mexico Bureau of Mines \& Mineral Resources, in cooperation with Los Alamos Scientific Laboratory. Santa Fe, New Mexico.

Kennedy, Kathryn L. 1983. A habitat type classification of the pinyon-juniper woodlands of the Lincoln National Forest, New Mexico. Pages 54-61 in Proceedings of the Workshop on Southwestern Habitat Types (W.H. Moir and Leonard Hendzel, technical coordinators), USDA Forest Service, Southwestern Region, Albuquerque, New Mexico.

Kessell, S.R. 1976. Gradient modeling: A new approach to fire modeling and widlerness resource management. Environmental Management 1:39-48.

Kessell, S.R. and P.J. Cattelino. 1978. Evaluation of a fire behavior information integration system for southern California chaparral wildlands. Environmental Management 2:135-159.

Koch, Steven W., Thomas K. Budge and Randy G. Balice. 1997. Development of a land cover map for Los Alamos National Laboratory and vicinity. LA-UR-97-4628, Los Alamos National Laboratory, Los Alamos, New Mexico.

Komarkova, Vera, Robert R. Alexander, and Barry C. Johnston. 1988. Forest vegetation of the Gunnisson and parts of the Uncompahgre National Forests: A preliminary habitat type classification. General Technical Report RM-163, Rocky Mountain Forest and Range Experiment Station, Fort Collins, Colorado.

Lambert, J.M. and M.B. Dale. 1964. The use of statistics in phytosociology. Advances in Ecological Research 2:59-99.

Layser, Earle F. and Gilbert H. Schubert. 1979. Preliminary classification for the coniferous forest and woodland series of Arizona and New Mexico. Research Paper RM-208, USDA Forest Service, Rocky Mountain Forest and Range Experiment Station, Fort Collins, Colorado.

Lindsay, M.M. and S.P. Bratton. 1979. The vegetation of grassy balds and other high elevation disturbed areas in the Great Smoky Mountains, National Park. Bulletin of the Torrey Botanical Club 106:264-275. 
Minore, Don. 1979. Comparative autecological characteristics of northwestern tree species --- a literature review. General Technical Report PNW-87, USDA Forest Service, Pacific Northwest Forest and Range Experiment Station, Portland, Oregon.

Moir, William H. and Leonard Hendzel (Technical coordinators). 1983. Proceeding of the workshop on southwestern habitat types. USDA Forest Service, Southwestern Region, Albuquerque, New Mexico.

Moir, William H. and John A. Ludwig. 1979. A classification of spruce-fir and mixed conifer habitat types of Arizona and New Mexico. Research Paper RM-207, USDA Forest Service, Rocky Mountain Forest and Range Experiment Station, Fort Collins, Colorado.

Mueggler, Walter F. 1988. Aspen community types of the Intermountain Region. General Technical Report INT-250, USDA Forest Service, Intermountain Research Station, Ogden, Utah.

Mueggler, Walter F. and Robert B. Campbell, Jr. 1986. Aspen community types of Utah. General Technical Report INT-362, USDA Forest Service, Intermountain Research Station, Ogden, Utah.

Mueller-Dombois, Dieter and Heinz Ellenberg. 1974. Aims and methods of vegetation ecology. John Wiley \& Sons, New York, New York.

Nyhan, J.W., L.W. Hacker, T.E. Calhoun, and D.L. Young. 1978. Soil survey of Los Alamos County, New Mexico. LA-6779-MS, Los Alamos Scientific Laboratory, Los Alamos, New Mexico.

Orloci, L. and W. Stanek. 1979. Vegetation survey of the Alaska Highway, Yukon Territory: Types and gradients. Vegetatio 41:1-56.

Peet, Robert K. 1988. Forests of the Rocky Mountains. Pages 63-101 in North American Terrestrial Vegetation (M.G. Barbour and W.D. Billings, editors), Cambridge University Press, Cambridge, England.

Potter, Loren D. and Teralene Foxx. 1981. Vegetational mapping and fire history of Cerro Grande accession, Bandelier National Monument. Final report to the National Park Service on file at the Biology Department, University of New Mexico, Albuquerque, New Mexico.

Ratliff, Raymond D. and Rex D. Pieper. 1982. Approaches to plant community classification for range managers. Journal of Range Management Monograph Series, 1:1-10. 
Rehfeldt, G.E. 1974. Genetic variation of the Douglas-fir in the northern Rocky Mountains. Research Note INT-184, USDA Forest Service, Intermountain Forest and Range Experiment Station, Ogden, Utah.

Shepherd, R.F. 1959. Phytosociological and environmental characteristics of outbreak and non-outbreak areas of the two-year cycle spruce budworm, Choristoneura fumiferana. Ecology 40:608-620.

Thomas, G.P. 1958. The occurrence of the Indian paint fungus, Echinodontium tinctorium E. and E., in British Columbia. Canadian Department of Agriculture, Division of Forestry, Biology Publication 1041.

Thompson, D.C. 1980. A classification of the vegetation of Boothia Peninsula and the Northern District of Keewatin, N.W.T. Arctic 33:73-99.

USDA Forest Service. 1995. Forest and woodland habitat types (plant associations) of northern New Mexico and northern Arizona, edition 2. USDA Forest Service, Southwestern Region, Albuquerque, New Mexico.

Westfeld, M. 1953. Ecology and silviculture of the spruce-fir forests of eastern North America. American Journal of Forestry 51:422-430.

Whittaker, R.H. 1975. Communities and ecosystems, second edition. Macmillan Publishing Company, New York, New York. 


\section{Appendix A}

Correspondence Between the Common Names and Scientific Names of Plant Species 


\section{Correspondence Between the Common Names and}

Scientific Names of Plant Species

Common name

American vetch

Apache plume

Arizona peavine

Arizona valerian

Aspen

Bedstraw

Bitterweed

Blue grama

Bluegrass

Bottlebrush squirreltail

Bracken fern

Canadian violet

Chokecherry

Cliffbush

Colorado barberry

Dog violet

Douglas fir

Dwarf juniper

Dwarf mistletoe

Engelmann spruce

False Solomon's seal

Fendler meadowrue

Fendlerbush

Fleabane

Forest fleabane

Fringed brome

Gambel oak

Golden pea

Inkberry

June grass

Kentucky bluegrass

Kinnikinnik

Limber pine

Little bluestem

Louisiana wormwood

Mockorange

Mountain brome

Mountain mahogany

Mountain maple

Mountain muhly

Mountain parsley

Mountain snowberry

Muttongrass
Scientific name

Vicia americana

Fallugia paradoxa

Lathyrus arizonicus

Valeriana arizonica

Populus tremuloides

Galium aparine

Hymenoxys richardsonii

Bouteloua gracilis

Poa spp.

Sitanion hystrix

Pteridium aquilinum

Viola canadensis

Prunus virginiana

Jamesia americana

Berberis fendleri

Viola adunca

Pseudotsuga menziesii

Juniperus communis

Arceuthobium vaginatum

Picea engelmannii

Smilacina racemosa

Thalictrum fendleri

Fendlera rupicola

Erigeron spp.

Erigeron eximius

Bromus ciliatus

Quercus gambelii

Thermopsis pinetorum

Lonicera involucrata

Koeleria macrantha

Poa pratensis

Arctostaphylos uva-ursi

Pinus flexilis

Schizachyrium scoparium

Artemisia ludoviciana

Philadelphus microphyllus

Bromus marginatus

Cercocarpus montanus

Acer glabrum

Muhlenbergia montana

Pseudocymopterus montanus

Symphoricarpos oreophilus

Poa fendleriana 
Myrtle boxleaf

Narrowleaf hoptree

New Mexico locust

Ninebark

Nodding brome

Oceanspray

One-seed juniper

Oregon grape

Parry danthonia

Perky Sue

Pincushion cactus

Pine dropseed

Piñon

Ponderosa pine

Purple fruit prickly pear

Purple geranium

Pussytoes

Ragweed sagebrush

Rattlesnake plantain

Rocky Mountain clematis

Rocky Mountain iris

Rocky Mountain juniper

Scouler willow

Sedges

Sidebells

Skunkbush

Slender wheatgrass

Star flower

Subalpine fir

Sweet cicely

Thimbleberry

Timber oatgrass

Utah serviceberry

Virginia strawberry

Wax currant

Western baneberry

Western sedge

White fir

White Mountain sedge

Whitestem gooseberry

Whortleberry

Woodland strawberry

Woods' rose

Woolly cinquefoil

Wooton's senecio

Yarrow
Pachystima myrsinites

Ptelea trifoliata

Robinia neomexicana

Physocarpus monogynous

Bromus anomalus

Holodiscus dumosus

Juniperus monosperma

Berberis repens

Danthonia parryi

Hymenoxys argentea

Coryphantha vivipara

Blepharoneuron tricholepis

Pinus edulis

Pinus ponderosa

Opuntia phaeacantha

Geranium caespitosum

Antennaria parvifolia

Artemisia franserioides

Goodyera oblongifolia

Clematis pseudoalpina

Iris missouriensis

Juniperus scopulorum

Salix scouleriana

Carex spp.

Pyrola secunda

Rhus trilobata

Agropyron trachycaulum

Smilacina stellata

Abies lasiocarpa

Osmorhiza obtusa

Rubus parviflorus

Danthonia intermedia

Amelanchier utahensis

Fragaria virginiana

Ribes cereum

Actaea rubra

Carex occidentalis

Abies concolor

Carex geophila

Ribes inerme

Vaccinium myrtillus

Fragaria vesca

Rosa woodsii

Potentilla hippiana

Senecio wootonii

Achillea millefolium 


\section{Appendix B}

\section{Correspondence Between the Scientific Names and}

Common Names of Plant Species 


\section{Correspondence Between the Scientific Names and Common Names of Plant Species}

\begin{tabular}{ll}
\multicolumn{1}{c}{ Scientific name } & Common name \\
Abies concolor & White fir \\
Abies lasiocarpa & Subalpine fir \\
Acer glabrum & Mountain maple \\
Achillea millefolium & Yarrow \\
Actaea rubra & Western baneberry \\
Agropyron trachycaulum & Slender wheatgrass \\
Amelanchier utahensis & Utah serviceberry \\
Antennaria parvifolia & Pussytoes \\
Arceuthobium vaginatum & Dwarf mistletoe \\
Arctostaphylos uva-ursi & Kinnikinnik \\
Artemisia franserioides & Ragweed sagebrush \\
Artemisia ludoviciana & Louisiana wormwood \\
Berberis fendleri & Colorado barberry \\
Berberis repens & Oregon grape \\
Blepharoneuron tricholepis & Pine dropseed \\
Bouteloua gracilis & Blue grama \\
Bromus anomalus & Nodding brome \\
Bromus ciliatus & Fringed brome \\
Bromus marginatus & Mountain brome \\
Carex spp. & Sedges \\
Carex geophila & White Mountain sedge \\
Carex occidentalis & Western sedge \\
Cercocarpus montanus & Mountain mahogany \\
Clematis pseudoalpina & Rocky Mountain clematis \\
Coryphantha vivipara & Pincushion cactus \\
Danthonia intermedia & Timber oatgrass \\
Danthonia parryi & Parry danthonia \\
Erigeron spp. & Fleabane \\
Erigeron eximius & Forest fleabane \\
Fallugia paradoxa & Apache plume \\
Fendlera rupicola & Fendlerbush \\
Fragaria vesca & Woodland strawberry \\
Fragaria virginiana & Virginia strawberry \\
Galium aparine & Bedstraw \\
Geranium caespitosum & Purple geranium \\
Goodyera oblongifolia & Rattlesnake plantain \\
Holodiscus dumosus & Oceanspray \\
Hymenoxys argentea & Perky Sue \\
Hymenoxys richardsonii & Bitterweed \\
Iris missouriensis & Rocky Mountain iris \\
Jamesia americana & Cliffbush \\
Juniperus communis & Dwarf juniper \\
Juniperus monosperma & One-seed juniper \\
Juniperus scopulorum & Rocky Mountain juniper \\
& \\
\hline
\end{tabular}


Koeleria macrantha

Lathyrus arizonicus

Lonicera involucrata

Muhlenbergia montana

Opuntia phaeacantha

Osmorhiza obtusa

Pachystima myrsinites

Philadelphus microphyllus

Physocarpus monogynous

Picea engelmannii

Pinus edulis

Pinus flexilis

Pinus ponderosa

Poa spp.

Poa fendleriana

Poa pratensis

Populus tremuloides

Potentilla hippiana

Prunus virginiana

Pseudocymopterus montanus

Pseudotsuga menziesii

Ptelea trifoliata

Pteridium aquilinum

Pyrola secunda

Rhus trilobata

Ribes cereum

Ribes inerme

Robinia neomexicana

Rosa woodsii

Rubus parviflorus

Quercus gambelii

Salix scouleriana

Schizachyrium scoparium

Senecio wootonii

Sitanion hystrix

Smilacina racemosa

Smilacina stellata

Symphoricarpos oreophilus

Thalictrum fendleri

Thermopsis pinetorum

Vaccinium myrtillus

Valeriana arizonica

Vicia americana

Viola adunca

Viola canadensis
June grass

Arizona peavine

Inkberry

Mountain muhly

Purple fruit prickly pear

Sweet cicely

Myrtle boxleaf

Mockorange

Ninebark

Engelmann spruce

Piñon

Limber pine

Ponderosa pine

Bluegrass

Muttongrass

Kentucky bluegrass

Aspen

Woolly cinquefoil

Chokecherry

Mountain parsley

Douglas fir

Narrowleaf hoptree

Bracken fern

Sidebells

Skunkbush

Wax currant

Whitestem gooseberry

New Mexico locust

Woods' rose

Thimbleberry

Gambel oak

Scouler willow

Little bluestem

Wooton's senecio

Bottlebrush squirreltail

False Solomon's seal

Star flower

Mountain snowberry

Fendler meadowrue

Golden pea

Whortleberry

Arizona valerian

American vetch

Dog violet

Canadian violet 


\section{Appendix C}

\section{Preliminary Key to Major Land Cover Types}

in the Los Alamos Region, Revision 1 


\section{Preliminary Key to Major Land Cover Types in the Los Alamos Region, Revision 1}

This key is to be used as guidance for the identification of major types of land cover at the Los Alamos National Laboratory, Los Alamos County, and surrounding areas. It is designed for homogeneous areas that are at least 0.405 hectares $(1.0 \mathrm{acre})$ in total area or are significant linear features. Buildings, farm structures, pavement, utility corridors, or developments for other cultural purposes are not included in this classification.

1. Land is at least periodically flooded. Open water is present; or the land supports facultative or obligate hydrophytic plant species, is characterized by hydric soils; or the vegetation composition is influenced by nearby water; or the effects of recent flooding are evident.-.-........ Key A: Open Water, Wetlands, and Riparian Zones.

1. The land is variable but not periodically flooded or open water.

2. Land is covered by $<7$ percent vegetation. Land is primarily cobbles, boulders, bedrock, or bare ground.

Key B: Unvegetated Land.

2. Land covered by $\geq 7$ percent vegetation. 3

3. Land vegetated by an open woodland with at least 10 percent tree coverage.

Juniperus monosperma is the only tree species present, or Pinus edulis may also be present with $<5$ percent coverage. Key C: Juniper Savanna.

3. Vegetations structures are variable. Combinations of tree species are not as above. $-4$

4. Land is forested or wooded. Mature tree species are present with $\geq 10$ percent combined overstory coverage.

4. Land is not forested or wooded. Vegetation consists predominantly of shrub, forb, or graminoid species. If mature tree species are present, their total overstory coverage is $<10$ percent.

5. Picea engelmannii or Abies lasiocarpa dominate the overstory. --Key H: Spruce-Fir Forests

5. Picea engelmannii and Abies lasiocarpa are absent or present in the understory or midstory, but not dominant in the overstory. $-6$

6. Populus tremuloides is present with $\geq 20$ percent overstory coverage. Other tree species may also be present in the midstory or overstory.--------Key G: Aspen Forests

6. Populus tremuloides is not present with $\geq 20$ percent overstory coverage. Other tree species dominate the overstory.

7. Pseudotsuga menziesii or Abies concolor dominate the overstory.

7. Pseudotsuga menziesii and Abies concolor are absent or present in the understory or midstory, but not dominant in the overstory. 
8. Pinus ponderosa dominates the overstory. Key E: Ponderosa Pine Forests

8. Dominant tree species are Pinus edulis or Juniperus monosperma. Pinus ponderosa is absent or present, but not dominant in the overstory. Key D: Piñon-Juniper Woodlands

9. Tall ( $>1.5 \mathrm{ft}$ ) shrub species, such as Artemisia filifolia, Artemisia tridentata, Atriplex canescens, Cercocarpus montanus, Chrysothamnus nauseosus, Fallugia paradoxa, Opuntia imbricata, Quercus spp., Rhus trilobata, or Robinia neomexicana, are present with $\geq 15$ percent combined coverage.-----Key I: Shrublands

9. Tall shrub species are absent or with $<15$ percent combined cover. The vegetation is dominated by forbs and graminoids. Key J: Grasslands and Disturbed Areas

Key A: Open water, wetlands, and riparian zones. Land is at least periodically flooded or is open water. The land supports facultative or obligate hydrophytic plant species, is characterized by hydric soils; or the vegetation composition is influenced by nearby water; or the effects of past flooding are evident. These are marshes, lakes, rivers, streams, gallery forests, and other communities strongly influenced by the presence of water.

1. Land vegetated with $\geq 30$ percent cover.

1. Land not vegetated or plant cover is $<30$ percent.

2. Vegetation is dominated by Acer negundo, Juniperus monosperma, Populus angustifolia, Populus fremontii, or other riparian tree species. 3

2. Hydrophytic or riparian tree species are not present or present only as accidentals. ----o-4

3. Vegetation is dominated by Populus angustifolia or by $P$. fremontii. Acer negundo is not dominant. --_-Cottonwood (Populus spp.) Riparian

3. Vegetation is not dominated by either Populus angustifolia or P. fremontii. Acer negundo is dominant. --_- Box Elder (Acer negundo) Riparian

4. Salix spp. or Tamarix spp. is present with $\geq 30$ percent cover. 5

4. Obligate or facultative hydrophyte shrub species are absent or present with . <30 percent cover. Carex spp., Typha spp., Scirpus spp. or other obligate or facultative hydrophyte species are present with $\geq 30$ percent cover.

5. Vegetation dominated by Salix spp. Tamarix spp. is absent or rare. Sandbar Willow (Salix exigua) Wetland

5. Vegetation dominated by Tamarix spp. Salix spp. is absent or rare. Tamarisk (Tamarix spp.) Wetland 
6. Vegetation dominated by Typha spp. Grasses and sedges are rare or absent.

6. Vegetation dominated by grasses and sedges. Typha spp. is rare or absent. Cattail (Typha latifolia) Wetland Grass/Sedge Meadow

7. Area is $<75$ percent stones, boulders, or bedrock and is exposed for $\geq 50$ percent of the year. -----Sandbars/Mudflats

7. Substrate is various, but the land is covered by water $>50$ percent of the year. $-8$

8. Water is contained in a channel and flows, at least slowly. $-9$

8. Water is not contained in a channel or basin, and is standing or flows very slowly. --.-12

9. Water is relatively fast flowing over a high gradient. The substrate consists of rock, cobbles, or gravel with some patches of sand.

9. Water is relatively slow moving over a low gradient. Substrates are mainly sand and mud. River

10. The channel contains flowing water throughout the year. Permanent Stream 10. The channel contains flowing water for only part of the year. Intermittent Stream

11. Waterbody is $\geq 2 \mathrm{~m}$ ( $6.6 \mathrm{ft}$ ) deep, or $\geq 20$ acres in area. -Lake or Reservoir 11. Waterbody is not as above. Pond

Key B: Unvegetated land. The land is covered by $<7$ percent vegetation. The land is dominated by cobbles, boulders, bedrock, or bare ground. The land is not developed for industrial, urban, agricultural, residential, vehicle parking, or other cultural purposes.

1. Slopes are $>70$ percent. 2

1. Slopes are $\leq 70$ percent. $-3$

2. Substrate is a volcanic tuff. -Tuffaceous Cliff

2. Substrate is basalt. Basalt Cliff

3. Land is above 8,000 feet in elevation. Bouldery and cobbly outcrop is on a hillslope.

3. Land is below 8,000 feet in elevation. Bouldery and cobbly outcrop is on a lower slope.

-Felsenmeer -Basalt Talus

Key C: Juniper savanna. The landscape is an open or closed woodland. The dominant tree species is Juniperus monosperma. Other tree species, such as Pinus edulis, may also be present, but their combined coverage is $<5$ percent. 
1. Slopes $\geq 20$ percent and substrate is predominantly stones, cobbles, or boulders. Parent material is basalt. Understory plant species are various.

One-seed juniper (Juniperus monosperma) basalt talus

1. Slopes and ground surface otherwise. Parent material is various.

Bouteloua curtipendula $\geq 7$ percent cover.

-------One-seed Juniper (Juniperus monosperma)/Side-oats Grama (Bouteloua curtipendula)

Key D: Piñon-juniper woodlands. The landscape is an open or closed woodland. The dominant tree species are Juniperus monosperma or Pinus edulis. Other tree species are absent or present with $<7$ percent in combined coverage.

1. Bouteloua gracilis $\geq 7$ percent cover, Bouteloua gracilis is the dominant understory species in depauperate vegetation. Muhlenbergia montana is absent or present with

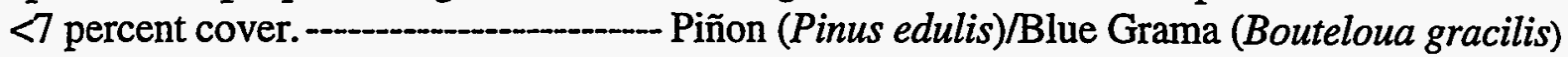

1. Bouteloua gracilis is absent or is present with $<7$ percent cover in well-developed vegetation. Muhlenbergia montana is present with $\geq 7$ percent cover.

Piñon (Pinus edulis)/Mountain Muhly (Muhlenbergia montana)

Key E: Ponderosa pine forests. The landscape is an open or closed forest. Pinus ponderosa is the dominant tree species, being present with cover $\geq 7$ percent. Juniperus monosperma and Pinus edulis may also be present, but other tree species are absent, occur as accidentals, or $<7$ percent in cover.

1. Shrub species, primarily Quercus spp., with $\geq 7$ percent cover are present in welldeveloped vegetation or are the dominant species in depauperate vegetation.---_-

1. Shrub species are absent or with $<7$ percent cover. 3

2. Quercus undulata is the dominant oak species.

-Ponderosa Pine (Pinus ponderosa)/Wavyleaf Oak (Quercus undulata)

2. Quercus gambelii is the dominant oak species.

Ponderosa Pine (Pinus ponderosa)/Gambel Oak (Quercus gambelii)

3. Bouteloua gracilis is present with $\geq 7$ percent cover. Muhlenbergia montana is absent or present with $<7$ percent cover.

Ponderosa Pine (Pinus ponderosa)/Blue Grama (Bouteloua gracilis)

3. Bouteloua gracilis is absent or present with $<7$ percent cover. Muhlenbergia montana is present with $\geq 7$ percent cover.

------Ponderosa Pine (Pinus ponderosa)/ Mountain Muhly (Muhlenbergia montana) 
Key F: Mixed conifer forests. The landscape is a montane forest. Trees $\geq 5 \mathrm{~m}$ (16 ft) tall with coverage $\geq 10$ percent are present. Pseudotsuga menziesii or Abies concolor are the dominant overstory species. Other tree species may also be present in the midstory or overstory.

1. Pseudotsuga menziesii is the dominant species in the overstory. Other tree species may also be present in the overstory or midstory.

-_._- Douglas Fir (Pseudotsuga menziesii)/Gambel Oak (Quercus gambelii)

1. Abies concolor is the dominant overstory species. Other tree species may also be present in the overstory or midstory.

2. Quercus gambelii is present with $\geq 7$ percent cover.

- White fir (Abies concolor)/Gambel Oak (Quercus gambelii)

2. Quercus gambelii is absent or present with $<7$ percent cover. $-3$

3. Arctostaphylos uva-ursi is present with $\geq 3$ percent cover. Erigeron eximius and Acer glabrum other forbs are absent.

White Fir (Abies concolor)/Kinnikinnik (Arctostaphylos uva-ursi)

3. Arctostaphylos uva-ursi is absent or present with $<3$ percent cover.

Erigeron eximius or Acer glabrum are dominant features of the understory.

4. Acer glabrum is present with $\geq 7$ percent cover. Erigeron eximius and other forbs may be abundant.

White Fir (Abies concolor)/Mountain Maple (Acer glabrum)

4. Acer glabrum is absent or present with $<7$ percent cover. Erigeron eximius and other forbs are dominant features of the understory. White Fir (Abies concolor)/Forest Fleabane (Erigeron eximius)

Key G: Aspen forests. The landscape is a montane to upper montane forest. Trees $\geq 5 \mathrm{~m}$ (16 ft) tall with coverage $\geq 12$ percent are present. Populus tremuloides is present in the overstory with $\geq 20$ percent coverage. Pseudotsuga menziesii, Abies concolor, or Picea engelmannii may also be present but are not dominant, individually or together, in the overstory.

1. Pteridium aquilinum is present with $\geq 7$ percent cover. Bromus anomalus and other forbs may be abundant.

Aspen (Populus tremuloides)/Bracken Fern (Pteridium aquilinum)

1. Pteridium aquilinum is absent or present with $<7$ percent cover. Bromus anomalus and other graminoids or forbs are dominant features of the understory. Aspen (Populus tremuloides)/Nodding brome (Bromus anomalus) 
Key H: Spruce fir forests. The landscape is an upper montane forest. Trees $\geq 5 \mathrm{~m}(16 \mathrm{ft})$ tall with coverage $\geq 10$ percent are present. Picea engelmannii is the dominant overstory species. Other tree species may also be present in the midstory or overstory.

1. Herbs and shrubs collectively $<10$ percent cover. Engelmann Spruce (Picea engelmannii)/Moss

1. Herbs and shrubs collectively $\geq 10$ percent cover. 2

2. Vaccinium myrtillus is present with $\geq 7$ percent cover. Erigeron eximius and other forbs may be abundant. Subalpine fir (Abies lasiocarpa)/Whortleberry (Vaccinium myrtillus)

2. Vaccinium myrtillus is present with $<7$ percent cover. Erigeron eximius and other forbs are the dominant feature of the understory. 3

3. Populus tremuloides is absent from the overstory or preset with $<12$ percent canopy cover. -Subalpine fir (Abies lasiocarpa)/Forest Fleabane (Erigeron eximius)

3. Populus tremuloides is present in the overstory with $\geq 12$ percent canopy cover. ------ Subalpine fir (Abies lasiocarpa)/Quaking Aspen (Populus tremuloides)

Key I: Shrublands. Tall $(>1.5 \mathrm{ft})$ shrub species are present with $\geq 15$ percent cover. Tree species are absent or not present with $\geq 10$ percent combined overstory coverage. The land is not developed for industrial, urban, agricultural, residential, or other cultural purposes.

1. Atriplex canescens is present with $\geq 7$ percent cover.

1. Atriplex canescens is absent or present with $<7$ percent cover. Four-wing Saltbush (Atriplex canescens)

2. Chrysothamnus nauseosus is present with $\geq 7$ percent cover.

Rabbit Brush (Chrysothamnus nauseosus)

2. Chrysothamnus nauseosus is absent or present with $<7$ percent cover.

3. Robinia neomexicana is present with $\geq 7$ percent cover. Quercus gambelii is absent or present with $<7$ percent cover.----New Mexico Locust (Robinia neomexicana)

3. Robinia neomexicana is absent or present with $<7$ percent cover. Quercus gambelii is present with $\geq 7$ percent cover. Gambel Oak (Quercus gambelii)

Key J: Grasslands and disturbed areas. Tall ( $>1.5 \mathrm{ft}$ ) shrub species are not present with $\geq 15$ percent cover. Tree species are absent or not present with $\geq 10$ percent combined overstory coverage. The vegetation is dominated by graminoids or forbaceous species. The land is not developed for industrial, urban, agricultural, residential, or other cultural purposes. 
1. Bouteloua gracilis is present with $\geq 7$ percent cover.

1. Bouteloua gracilis is absent or present with $<7$ percent cover.

2. Bouteloua eriopoda is codominant with Bouteloua gracilis.

Blue Grama (Bouteloua gracilis)/Black Grama (Bouteloua eriopodoa)

2. Bouteloua eriopoda is absent or present with $<7$ percent cover. -Blue Grama (Bouteloua gracilis)

3. Native grasses and sedges are present with $\geq 7$ percent cover.

Elevations are at least 8,000 feet.

3. Native grasses and sedges are absent or present with $<7$ percent

cover. Elevations are $<8,000$ feet.

Disturbed Areas

4. Elevations are above $2,743 \mathrm{~m}(9,000 \mathrm{ft})$ and topographic positions are southerly and southwesterly slopes.

-Montane Grassland

4. Elevations are typically lower and topographic positions are various.

-Montane Meadow 